\title{
Eco-Efficient Ventilated Facades Based on Circular Economy for Residential Buildings as an Improvement of Energy Conditions
}

\author{
Pilar Mercader-Moyano ${ }^{1, *(\mathbb{D}}$, Paula Anaya-Durán ${ }^{2} \mathbb{C}$ and Ana Romero-Cortés ${ }^{2}$ (D) \\ 1 Department of Building Construction I, Higher Technical School of Architecture, University of Seville, \\ Reina Mercedes Avenue 2, 41012 Seville, Spain \\ 2 Higher Technical School of Architecture, University of Seville, Reina Mercedes Avenue 2, 41012 Seville, Spain; \\ paulaandu26@gmail.com (P.A.-D.); romerocortesana@gmail.com (A.R.-C.) \\ * Correspondence: pmm@us.es
}

check for

updates

Citation: Mercader-Moyano, P.; Anaya-Durán, P.; Romero-Cortés, A. Eco-Efficient Ventilated Facades Based on Circular Economy for Residential Buildings as an Improvement of Energy Conditions. Energies 2021, 14, 7266. https:// doi.org/10.3390/en14217266

Academic Editors: Giorgio Ficco and Tomasz Cholewa

Received: 30 August 2021

Accepted: 26 October 2021

Published: 3 November 2021

Publisher's Note: MDPI stays neutral with regard to jurisdictional claims in published maps and institutional affiliations.

Copyright: (c) 2021 by the authors. Licensee MDPI, Basel, Switzerland. This article is an open access article distributed under the terms and conditions of the Creative Commons Attribution (CC BY) license (https:/ / creativecommons.org/licenses/by/ $4.0 /)$.

\begin{abstract}
In a planet with limited resources, climate change is a severe problem, intensified by industrial development. This is particularly important in the construction sector. According to the International Energy Agency (2021), the construction sector is responsible for 40\% of the global energy consumption and $36 \%$ of $\mathrm{CO}_{2}$ emissions. In this way, sustainable architectural solutions should be a priority in our fight against climate change, for it is necessary to propose solutions that help to reuse existing resources, thus reducing consumption. In this sense, the rehabilitation of buildings with solutions that favor the circular economy will become a key element in the construction sector. This work provides the design of a facade for building rehabilitation based on the circular economy paradigm, which is implanted in a model building as a case study. The HULC tool quantifies the improvement in energy efficiency that this rehabilitation entails when compared to a conventional facade. With the designed facade, a reduction in energy losses through the envelope is achieved, as well as an improvement in living conditions and environmental impact. Next, an analysis of the building's energy consumption and $\mathrm{CO}_{2}$ emissions is carried out with the Open BIM Quantities tool. This tool is used by construction researchers and professionals. Finally, the results show the improvements in the rehabilitation of the facade.
\end{abstract}

Keywords: circular economy; energy rehabilitation; energy efficiency; sustainability; eco-efficiency; facade; passive systems; recycling

\section{Introduction}

Climate change is an unquestionable reality. One of the reasons for it is the greenhouse effect generated by $\mathrm{CO}_{2}$ emissions. This causes an increase in the temperature of the planet as well as inequalities and imbalances that lead to higher energy consumption. The construction sector is a key player in this consumption problem.

To achieve sustainable development in buildings, we must talk about eco-efficient construction [1] and include the rehabilitation of current buildings that allows to stop consuming the ground, as well as the transformation of buildings that are obsolete. With this, we try to satisfy human needs, caring for and respecting the environment, reducing energy consumption, and, therefore, favoring the economy, especially in these moments in history where our world economy is being drastically damaged as a consequence. of the pandemic caused by COVID-19, as you can see in Figure 1.

Figure 1 shows the evolution of GDP in different countries. It reflects the great impact that the pandemic derived from COVID-19 has had on the global economy. It is essential to promote sustainable practices to reactivate the world economy. There are projects that propose sustainable constructions at low economic cost [4]. An example is the circular economy. This is an economic model in which products participate in a closed life cycle that reduces energy and economic costs in the manufacturing stage. 


\section{OF INFLUENTIAL COUNTRIES IN EUROPE AND LATIN AMERICA}

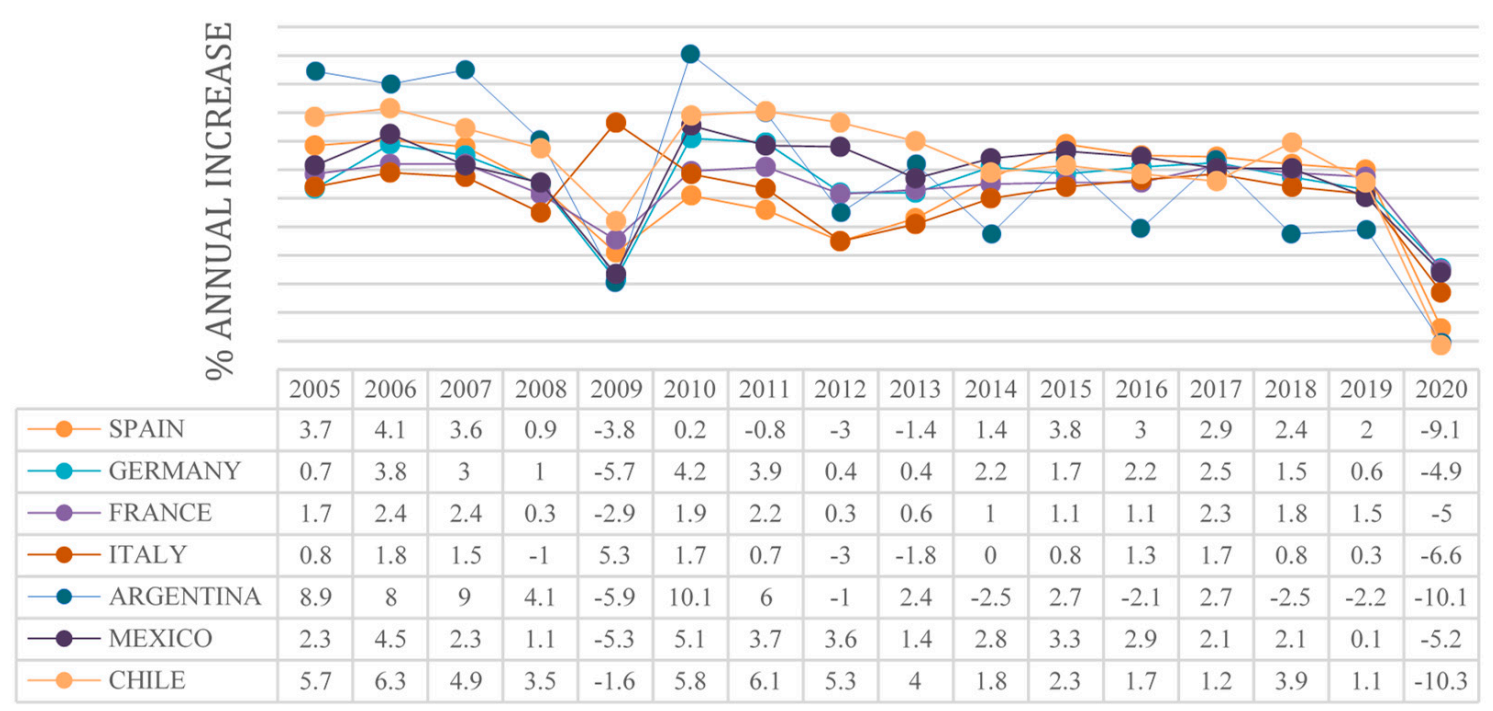

Figure 1. Annual evolution of the GDP (Gross Domestic Product) of influential countries in Europe and Latin America. Data obtained from Eurostat [2] and Cepalstat [3].

The construction sector is decisive in terms of energy consumption and $\mathrm{CO}_{2}$ emissions. According to data from the International Energy Agency [5] and the European Environment Agency [6], the construction sector is responsible for $40 \%$ of world energy consumption, $36 \%$ of $\mathrm{CO}_{2}$ emissions, and generates 9000 million tons of construction waste. This is why measures are currently being developed that intend to replace the linear economy with the circular economy.

In 2010, The European Commission issued a document titled: "Europe 2020. A strategy for smart, sustainable and inclusive growth" [7]. This document establishes the main strategies to achieve the objectives of Horizon 2020. Subsequently, in the years 2015 [8], 2016 [9], 2017 [10], and 2019 [11], a series of communications were published by the European Commission in which measures were proposed to favor the implementation of the circular economy and Eco-design criteria.

The formation of strategies to achieve the objectives set for 2050 for a climate neutral Europe has become very important. As mentioned previously, the construction sector is one of the main contributors to climate change. For this reason, it is essential to promote sustainable practices from the construction sector. Zero energy buildings (NZEB) or innovative construction solutions $[12,13]$ are fundamental elements in the fight against climate change. However, the improvements in new constructions are not enough because according to the European Commission, $70 \%$ of buildings in Europe are energy inefficient. For this reason, all European countries should get involved in the so-called "wave of renovation of public and private buildings", to improve the European built park [14]. The facade is the part of the building where the most energy is lost [15], because of this, it is essential to develop facades for the rehabilitation of buildings. In recent years, plenty of studies have been developed to analyze the energy improvements involved in the implementation of ventilated facades as rehabilitation [15-17].

The location of buildings is a fundamental parameter that has great influence on their energy development [18-20]. In new construction, it is necessary to take into account the location of the building in order to develop energy-efficient buildings that adapt to the surrounding climate. In the case of built buildings, it is necessary to develop rehabilitation proposals so that the buildings have an energy performance according to the place where they are. In this work, a facade for rehabilitation is developed so it is necessary to establish the location of the building that we will analyze. The scope of application will be the 
areas that have warm or temperate climates. These areas have greater impact in terms of energy consumption. The use of electricity and energy to provide thermal comfort in hot climate areas represents more than $30 \%$ of all electricity and energy consumption in the residential sector. [21] In addition, these areas of the planet are the most populated of the planet. Specifically, the Mediterranean climate is a type of temperate climate. In recent years, studies have been carried out on the energy behavior of buildings in these areas of the planet [22-24]. The need to propose eco-efficient construction solutions that reduce the energy impact of buildings already built-in areas with a Mediterranean climate is evident. For this reason, we will choose Spain (located in southern Europe) as the location for the development of the work.

The Government of Spain has published a series of documents in order to raise awareness among the most relevant professional sectors in the country. The main purpose of these documents is to promote sustainable constructions, to include eco-design in the product manufacturing process, to reduce construction demolition waste, and to promote the transition towards a circular economy and to be low in carbon in order to reduce environmental impacts $[25,26]$.

Focusing on the Spanish buildings built and their state of conservation, according to data from the National Statistics Institute [27], in Spain in 2011, there were 9,814,785 buildings and $25,208,623$ homes, 3,445,365 of them empty. Of the 25 million homes, 18 million are primary. According to its age, the park built in Spain consists of almost 3 million buildings with more than 50 years, which represents $30 \%$ of the total built.

As shown in Figure 2, is the Spanish residential park, the type of multi-family residential building that predominates for the most part. This typology is the one with the highest percentage that requires a priority intervention in relation to its state of conservation. This makes this building typology the most deteriorated within the Spanish built park.

DISTRIBUTION OF HOUSING ACCORDING TO AGE AND TYPE

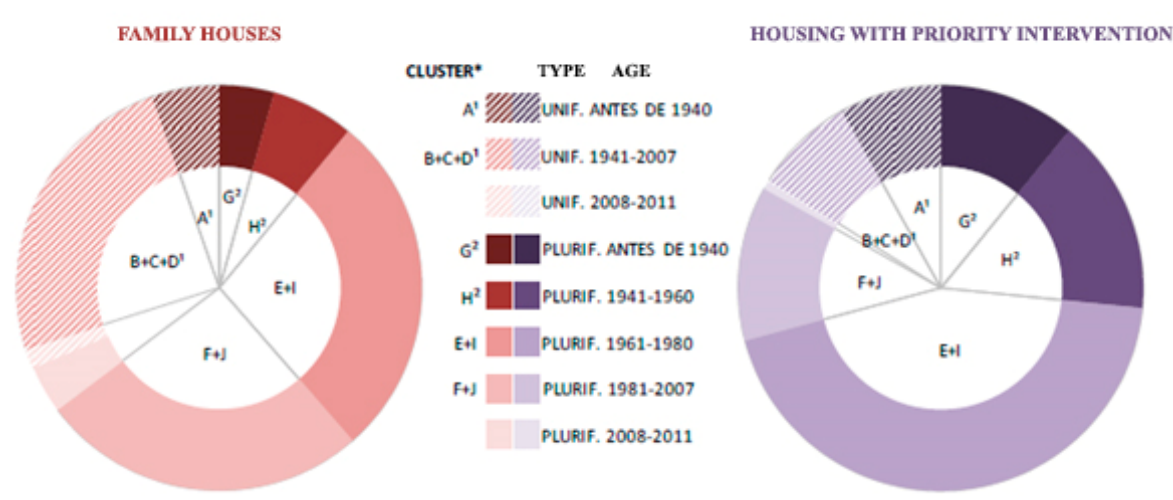

Figure 2. Distribution of the existing residential park according to age and type. Comparison of the family housing stock and the priority intervention stock. Extracted from "Analysis of the characteristics of residential building in Spain in 2011. Volume II. State and regional summary files", Ministry of Public Works, 2014 [28].

Around 51\% of the current built residential park was built before 1979, the year in which the Basic Building Standard on thermal conditions in buildings was published. Prior to that moment, there were no regulations that limited energy demand and consumption. A total of $92 \%$ of the built residential stock in Spain was built before the Technical Building Code (published in 2006), which introduced stricter restrictions. For these reasons, a large part of the buildings in Spain are energy inefficient. On the other hand, energy consumption in the residential sector in Spain accounts for $17 \%$ of total national energy and $25 \%$ in the European Union [29]. This is why new policies are beginning to place great value on energy renovation. In addition, the rehabilitation of houses in Spain has a lag of up to 20 years with respect to Europe, which makes it even more urgent to increase the number of rehabilitated properties. If these projects include constructive solutions with materials with low environmental impact, the state of the planet will be considerably improved [30]. 
Energy rehabilitation reduces energy consumption in buildings and represents financial savings. However, the priority must be to achieve healthy spaces, improve living conditions and greater thermal comfort, in addition to ventilation, a fundamental aspect to reduce COVID-19 infections. A study shows that air recirculation can lead to favorable heat gains during $10 \%$ of the winter, which is why ventilated facades are among the existing measures to reduce energy demand in buildings [31].

All over the world, projects are currently being carried out focused on the development of building rehabilitation processes. The objective of these projects is to reduce the environmental impact and pollution generated by the new plant works. Articles such as Eco-Efficient Analysis of a Refurbishment Proposal for a Social Housing [32] are published in which is carried out the environmental analysis of social housing and the improvements achieved with its rehabilitation, Figure 3.

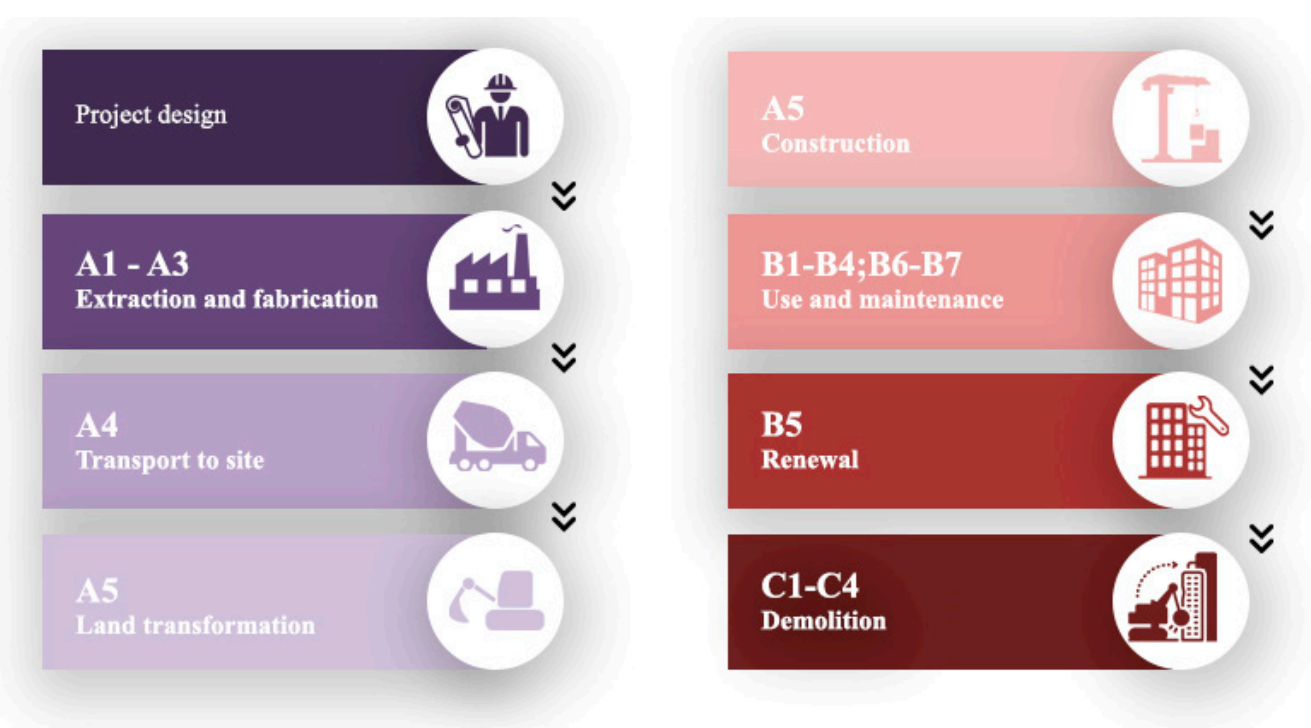

Figure 3. Life cycle of construction materials by stages in ISO 14040. Own elaboration with data extracted from "Study of footprints in the life cycle of the residential building", Rivero-Camacho C., 2020 [21].

Therefore, it can be said that a large part of the current built park requires improvements that would be achieved through rehabilitation. This will boost the economy, help combat climate change, and decrease energy poverty and gentrification.

In addition to this, it is essential to promote projects based on the circular economy, applied to architecture and construction in order to reduce $\mathrm{CO}_{2}$ emissions and energy consumption in the production and manufacturing processes (A1-A3) of materials of construction. The extraction and manufacturing stage of the products (A1-A3) is one of those that causes a higher energy cost for the environment. This is due to the amount of machinery that is used in this process and all the processes that are necessary to generate the construction materials. That is why this research focuses on it, where a detailed study of the materials that composed the facades is carried out. In order to be able to reflect the most relevant values and extract the general data energy cost of the facades. This stage directly affects the rehabilitation stage (B5), the other important part of this project. By making an improvement on an existing building, it is avoided to consume resources again and, therefore, to reduce said emissions.

\section{Materials and Methods}

After analyzing the European building situation, we found that it is necessary to promote new projects that involve eco-efficient and sustainable construction solutions. In this project, is designed a rehabilitation proposal developed for buildings whose energy 
performance is not efficient. This proposal focuses on the design of a facade based on the circular economy using materials with a low environmental impact.

\section{Methodology}

To achieve the main objective of the project, it is necessary to carry out the work in detail, establishing a series of stages with different parts in Figure 4.

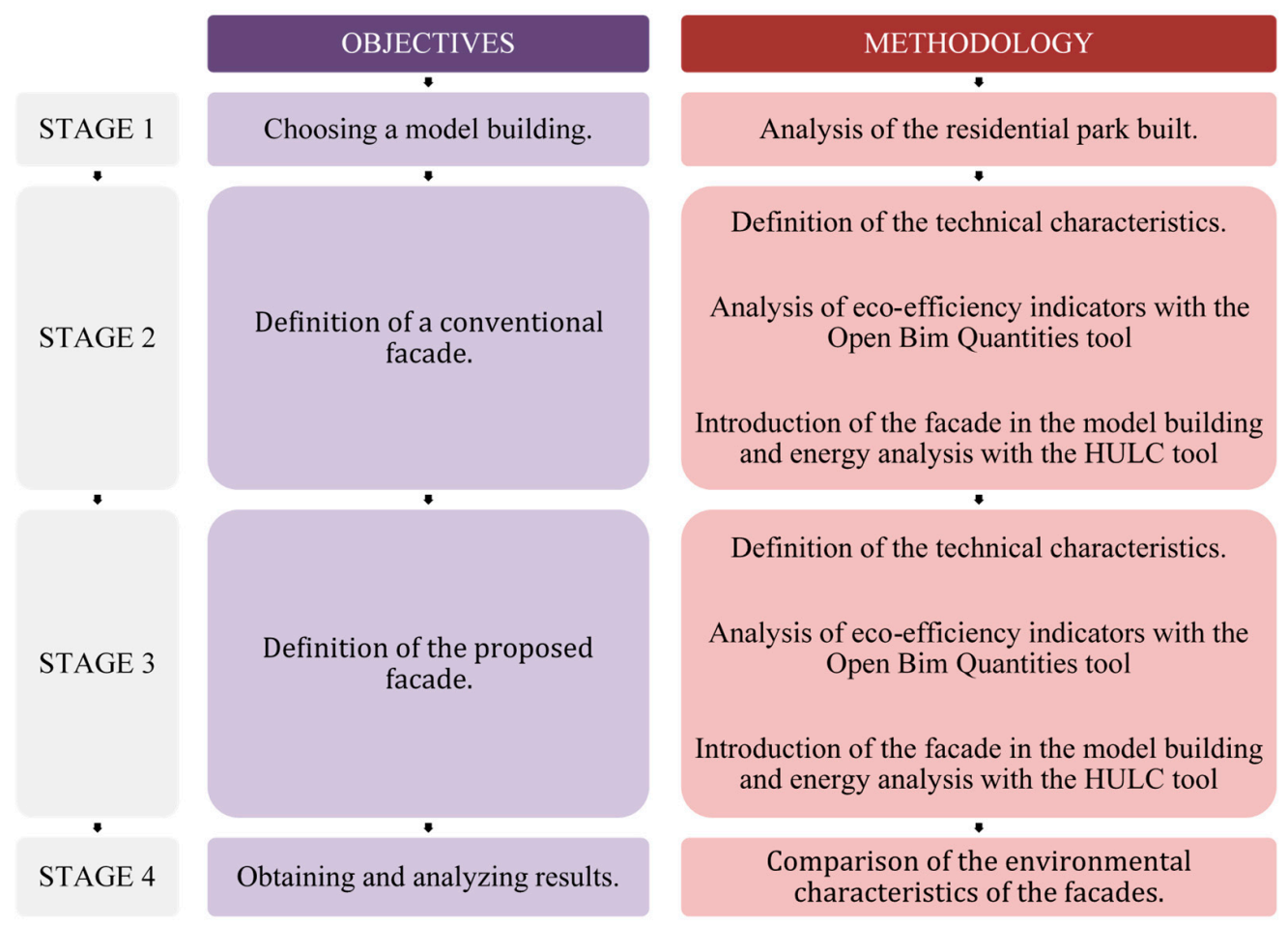

Figure 4. Outline of the project development stages related to the proposed objectives and the methodology followed to carry out the project.

For the development of this project, it is essential to compare the designed facade proposal with conventional facade models to verify that the designed facade really represents an advance in terms of sustainability and eco-efficiency. In stage 1 of the process, a model building is chosen on which the study of its energy performance with the different facades is carried out.

As previously explained, the model building will be located in Spain since it corresponds to a temperate climate (Mediterranean climate). The model building is located in Seville because it complies with the climatic characteristics previously exposed. This building is located in "Polígono San Pablo" and dates from 1962. The building has got 4 floors, with two houses per floor, for a total of 8 houses. It has a rectangular plan with dimensions of $22.30 \mathrm{~m}$ wide, by $7.50 \mathrm{~m}$ deep. Each house has around $72 \mathrm{~m}^{2}$ of living-dining room, kitchen, laundry room, bathroom, toilet, four bedrooms, and distribution space, as shown in the planimetry in Figure 5.

In stages 2 and 3, the morphology of the two facades analyzed and the products that compose them are defined. First, a facade established as conventional is developed and then the facade proposal for the rehabilitation to be able to compare the results obtained and make sure that the proposal represents an energy improvement.

The energy consumption and $\mathrm{CO}_{2}$ emissions generated in the manufacturing process of the products of the two predefined facades are exposed. The percentage of recycled product that they contain is also reflected. To obtain these data, manual calculations are carried out with data extracted from proven sources. Furthermore, the mentioned values are obtained through the Open BIM Quantities tool [34]. To obtain these last data, it is necessary to carry out a 3D modeling in the CYPE Architecture tool [35], see Figure 6. 

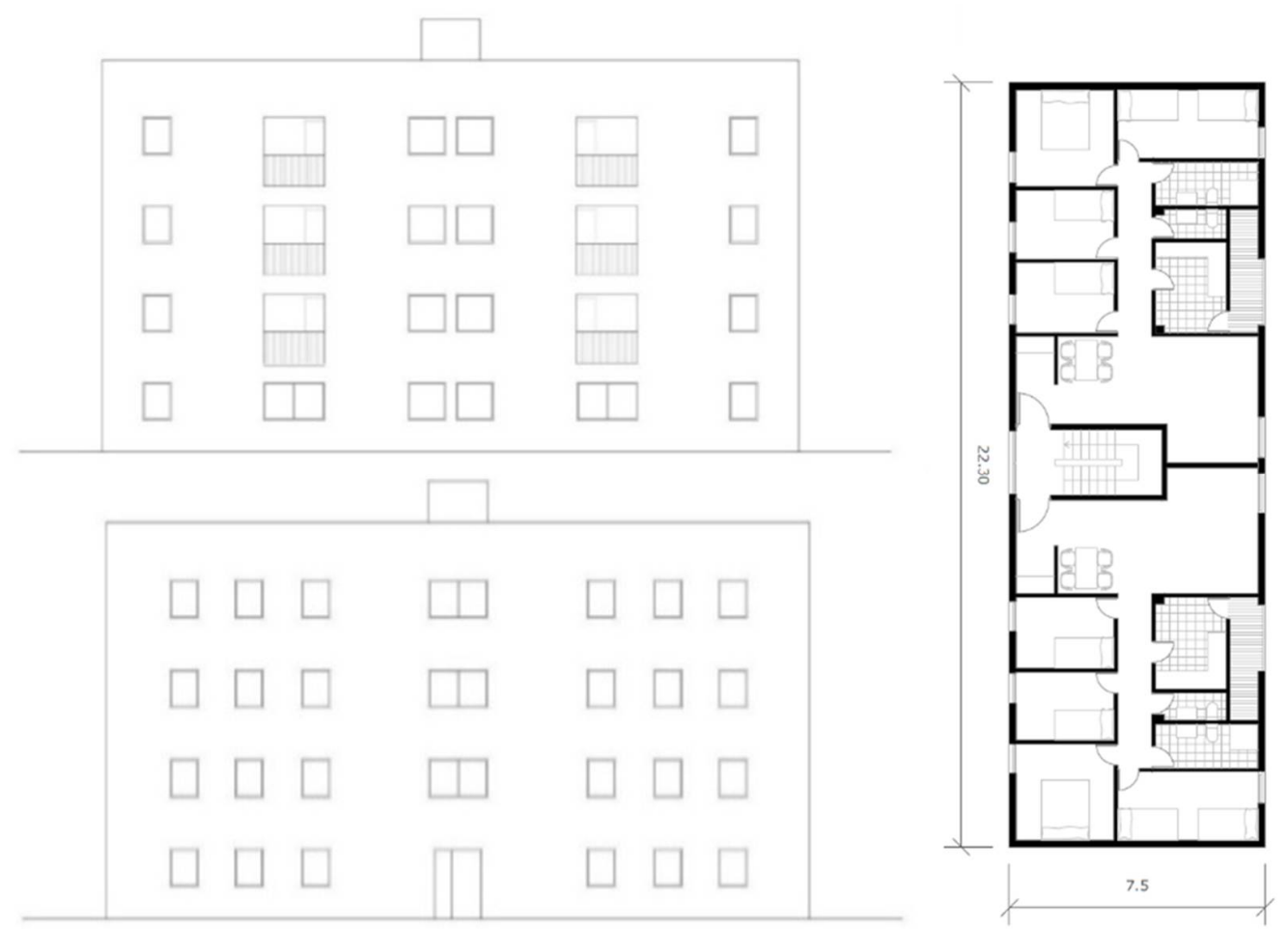

Figure 5. Planimetry of the simulated building. From top to bottom: rear elevation (north), standard plan, and front elevation (south). Own elaboration with data extracted from. "Typological analysis of linear social housing blocks: Spain 1950-1983. The case of Western Andalusia" [33].
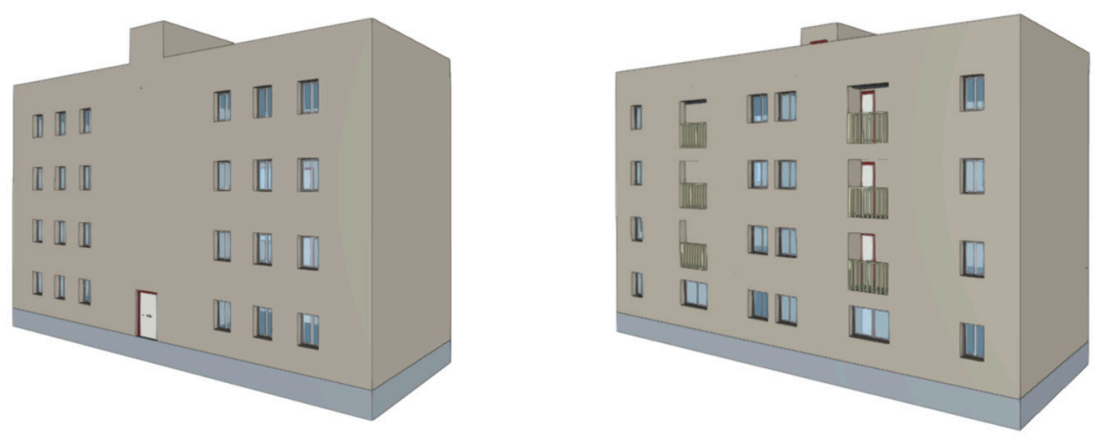

Figure 6. Three-dimensional modeling of the building chosen as a case study. Modeling made in the CYPE Architecture tool.

The composition of the building's constructive elements is defined using the CYPE Price Generator database [36]. The energy consumption values and the $\mathrm{CO}_{2}$ emissions of the products are analyzed. A study is carried out to analyze the energy performance of building with the different facades. This analysis is carried out through the monitoring of a model building using the LIDER/CALENER Unified Tool (HULC) [37], which report with the energy certification of the buildings. The location of the building is essential for the development of energy analysis. A hypothetical situation is proposed in which the model building has no buildings around it. This fact affects when calculating, since they act as shadow elements. Once all these data have been entered, the model shown in Figure 7 is obtained.

In this program, the model is first introduced by adding a fictitious floor where the different spaces and construction elements that make up the first floor are inserted, and so on with the successive floors. Next, the constructive characteristics of all the elements that make up the building are assigned, which allows making the checks for compliance with the CTE-DB-HE [38]. 


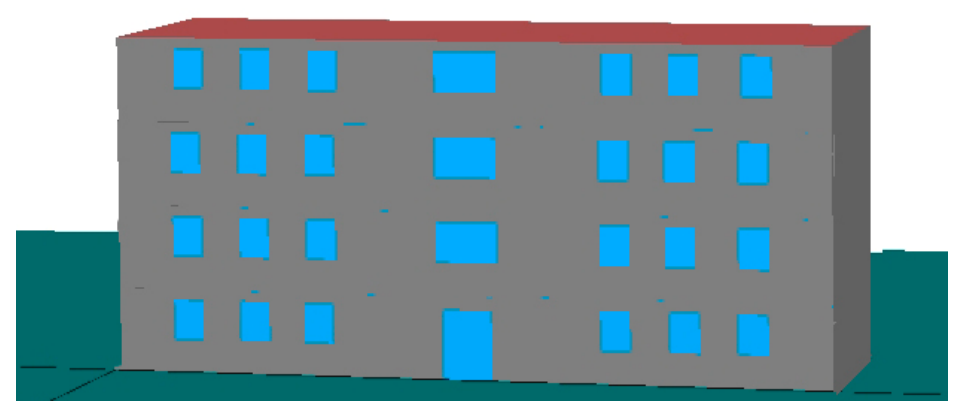

Figure 7. Building monitored in the HULC program. Own elaboration with images extracted from "LIDER-CALENER Unified Tool”.

Finally, in stage 4, the results obtained after the development of the analyses is carried out are graphically displayed in order to draw the pertinent conclusions. In this stage, a comparison is made of the characteristics of the enclosure materials, as well as the energy performance and the emissions and waste produced by the materials used.

\section{Analysis of the Facades}

\subsection{Facade Eco-Efficiency Indicators}

First of all, it is needed to study the environmental impact of the defined facades. Thus, it is necessary to carry out an analysis of the materials that compose them from the point of view of eco-efficiency and the sustainability of construction systems. This is essential to promote an action plan against climate change and boost the revitalization of the circular economy in the construction sector.

Three eco-efficiency indicators are defined: Energy consumption and $\mathrm{CO}_{2}$ emissions generated in the manufacturing stage of the products that make up the facades analyzed. Finally, the amount of recycled product is included in the materials that make up the facades.

Raising a general definition, we can establish that the energy consumption factor is the amount of energy necessary to carry out a production process. In the field of construction and architecture, energy consumption is the amount of energy used to manufacture a building element. This indicator is quantitatively expressed in $\mathrm{MJ} / \mathrm{m}^{2}$. The most unfavorable energy consumption values are those whose value is higher.

The $\mathrm{CO}_{2}$ emissions are defined as the amount of carbon dioxide emissions emitted during the manufacturing process of an item. In the field of construction and architecture, we will consider $\mathrm{CO}_{2}$ emissions as all those derived from the manufacturing process of materials. $\mathrm{CO}_{2}$ emissions are quantitatively expressed in $\mathrm{kgCO}_{2} / \mathrm{m}^{2}$. The most unfavorable energy consumption values are those whose value is higher.

The amount of recycled material that contains the elements of the facades is defined as a percentage that will reflect the amount of recycled product that is included in the manufacturing stage of the products.

These indicators are the most used to make a diagnosis of materials in terms of sustainability and environmental impact. This is so because these are the parameters that reveal the most unfavorable and relevant values of the products [39].

Next, the technical characteristics of the conventional facade and the proposed rehabilitation facade are defined. In addition, the following section includes tables that reflect the values of the four indicators mentioned associated with the products that make up the facades analyzed.

\subsection{Conventional Facade}

The characteristics of the conventional façade, Figure 8, have been obtained from the article Minimizing the environmental impact in the execution of facades through the use of recycled materials [40], BCCA (Andalusian Construction Costs Base) [41] and Catalogue of construction details of the CTE-2018 [42]. 


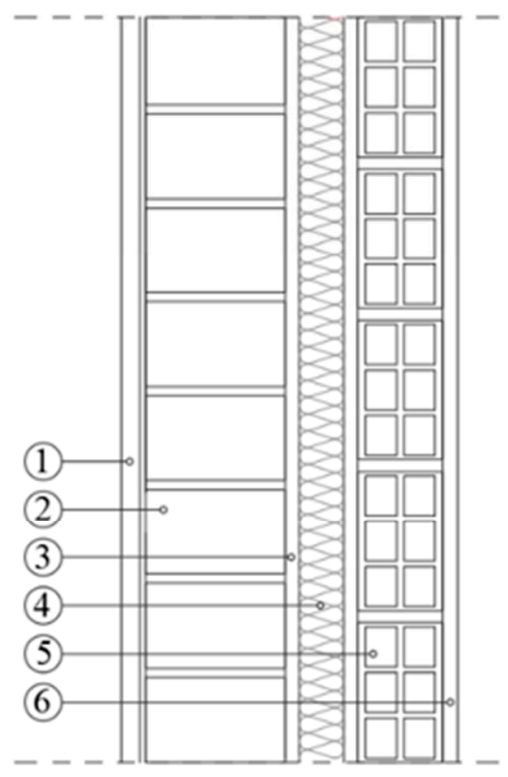

1. Exterior coating of Quintana Gray granite slabs, dimensions of the pieces of $40 \times 40 \times 2 \mathrm{~cm}$, glued to main layer by cement mortar.

2. Main layer made of waterproof perforated ceramic brick, $24 \times 11.5$ $\times 5 \mathrm{~cm}$, compressive strength $25 \mathrm{~N} / \mathrm{mm}^{2}$. Horizontal and vertical joints of $10 \mathrm{~mm}$ thick, received with industrial cement mortar M5 CEM II/AL $32.5 \mathrm{~N}$.

3. Busbar layer composed of cement mortar M-2.5.

4. Insulation by rigid polyurethane foam, $50 \mathrm{~mm}$ thick, $45 \mathrm{~kg} / \mathrm{m}^{3}$ density. $21 \times 11.5 \times 7 \mathrm{~cm}$.

5. Double hollow brick partition, compressive strength $5 \mathrm{~N} / \mathrm{mm}^{2}$.

6. Inner coating by means of a C6 thin-layer gypsum plaster on a previously lined surface.

Lacquered aluminum window frame, for forming an aluminum window, hinged that can be opened to the inside.

Figure 8. Section of conventional facade. Material definition according to BCCA [41] and construction price generatorCYPE Engineers [36].

Table 1 shows the values of energy consumption and $\mathrm{CO}_{2}$ emissions generated in the manufacturing stage of the products that compose the conventional facade. The data shown in the first two columns of the table have been calculated manually. These calculations are included in Appendix A, Table A1. On the other hand, the data reflected in the last two columns of the table have been extracted from the CYPE Price Generator database [36].

Table 1. Environmental Impact generated by the construction elements that make up the conventional facade.

\begin{tabular}{|c|c|c|c|c|}
\hline Product & $\begin{array}{c}\text { Energy } \\
\text { Consumption } \\
\mathrm{MJ} / \mathrm{m}^{2}\end{array}$ & $\begin{array}{c}\mathrm{CO}_{2} \\
\text { Emissions } \\
\mathrm{KgCO}_{2} / \mathrm{m}^{2}\end{array}$ & $\begin{array}{c}\text { Energy } \\
\text { Consumption } \\
\mathrm{MJ} / \mathrm{m}^{2}\end{array}$ & $\begin{array}{c}\mathrm{CO}_{2} \\
\text { Emissions } \\
\mathrm{KgCO}_{2} / \mathrm{m}^{2}\end{array}$ \\
\hline $\begin{array}{l}\text { Natural Stone }\left(\mathrm{EC}^{1}\right) \\
\text { Source } 2 / \text { Source } 3\end{array}$ & 12.80 & 20.00 & 88.68 & 2.04 \\
\hline $\begin{array}{c}\text { Polyurethane Foam }\left(\mathrm{TI}^{2}\right) \\
\text { Source } 2 / \text { Source } 3\end{array}$ & 315.00 & 46.49 & 340.65 & 16.53 \\
\hline $\begin{array}{l}\text { Perforated Brick }\left(\mathrm{ML}^{3}\right) \\
\text { Source } 1 / \text { Source } 3\end{array}$ & 441.00 & 41.16 & 406.52 & 18.75 \\
\hline $\begin{array}{l}\text { Double Hollow Brick }\left(\mathrm{IL}^{4}\right) \\
\text { Source } 1 / \text { Source } 3\end{array}$ & 168.48 & 12.55 & 212.22 & 11.30 \\
\hline $\begin{array}{l}\text { Plaster Coating }\left(\mathrm{IC}^{5}\right) \\
\text { Source } 2 / \text { Source } 3\end{array}$ & 19.80 & 1.44 & 48.53 & 2.16 \\
\hline $\begin{array}{c}\text { Cement Mortar }\left(\mathrm{U}^{6}\right) \\
\text { Source } 1 / \text { Source } 3\end{array}$ & 28.00 & 38.22 & 13.05 & 1.01 \\
\hline $\begin{array}{l}\text { Lacquered Aluminium }\left(\mathrm{WF}^{7}\right) \\
\text { Source } 2 / \text { Source } 3\end{array}$ & 235.44 & 34.60 & 359.36 & 9.51 \\
\hline
\end{tabular}

${ }^{1}$ EC: Exterior Coating; ${ }^{2}$ TI: Thermal Insulation; ${ }^{3}$ ML: Main Layer; ${ }^{4}$ IL: Inner Layer; ${ }^{5}$ IC: Inner Coating, ${ }^{6} \mathrm{U}$ : Unions; ${ }^{7}$ WF: Window frame. Data extracted from the BEDEC database (Source 1) [43], Doctoral Thesis: Mercader Moyano, Pilar (2010). Quantification of the resources consumed and $\mathrm{CO}_{2}$ emissions produced in the constructions of Andalusia and its implications in the Kyoto protocol-Doctoral thesis, U. Seville. (Source 2) [44] and from the CYPE Price Generator database (Source 3) [36].

Most of the values obtained by manual calculation and those obtained from the chosen database are similar and so we assume that they are reliable. The only disparities between values appear in the energy consumption of natural stone. This element has a value of $12.80 \mathrm{MJ} / \mathrm{m}^{2}$ extracted from the manual calculation and $88.68 \mathrm{MJ} / \mathrm{m}^{2}$ extracted from 
the database. Cement mortar $\mathrm{CO}_{2}$ emissions presents a great disparity. By the manual calculation we obtain $34.60 \mathrm{kgCO}_{2} / \mathrm{m}^{2}$ and from the database we obtain $9.51 \mathrm{kgCO}_{2} / \mathrm{m}^{2}$.

First, the manually calculated values are analyzed. The perforated brick has the most unfavorable values, its energy consumption is $441.00 \mathrm{MJ} / \mathrm{m}^{2}$ and it emits $41.16 \mathrm{kgCO}_{2} / \mathrm{m}^{2}$. The polyurethane foam thermal insulation also presents high values, its energy consumption is $315.00 \mathrm{MJ} / \mathrm{m}^{2}$ and emits $46.49 \mathrm{kgCO}_{2} / \mathrm{m}^{2}$. In this case, the lowest values are found in the cement mortar used for the joints of the elements. Second, the data extracted from the CYPE Price Generator database is analyzed [36]. The most unfavorable value is also presented in perforated brick. Its energy consumption is $406.52 \mathrm{MJ} / \mathrm{m}^{2}$ and it generates $18.75 \mathrm{kgCO}_{2} / \mathrm{m}^{2}$. Aluminum window frame presents high values, having an energy consumption of $359.36 \mathrm{MJ} / \mathrm{m}^{2}$ and generating $9.51 \mathrm{kgCO} 2 / \mathrm{m}^{2}$.

Table 2 shows the unified values of energy consumption and $\mathrm{CO}_{2}$ emissions extracted from Table 1. The highest values have been taken to propose the most unfavorable analysis.

Table 2. Unification of environmental impact values generated by the construction elements that make up the conventional facade.

\begin{tabular}{|c|c|c|}
\hline Producto & $\begin{array}{l}\text { Energy Consumption } \\
\mathrm{MJ} / \mathrm{m}^{2}\end{array}$ & $\begin{array}{c}\mathrm{CO}_{2} \text { Emissions } \\
\mathrm{KgCO}_{2} / \mathrm{m}^{2}\end{array}$ \\
\hline $\begin{array}{l}\text { Natural Stone (EC) } \\
\text { Source 3/Source } 2\end{array}$ & 88.68 & 20.00 \\
\hline $\begin{array}{l}\text { Polyurethane Foam (TI) } \\
\text { Source 3/Source } 2\end{array}$ & 340.65 & 46.49 \\
\hline $\begin{array}{c}\text { Perforated Brick (ML) } \\
\text { Source } 1\end{array}$ & 441.00 & 41.16 \\
\hline $\begin{array}{l}\text { Double Hollow Brick (IL) } \\
\text { Source 3/Source } 1\end{array}$ & 212.22 & 12.55 \\
\hline $\begin{array}{c}\text { Plaster Coating (IC) } \\
\text { Source } 3\end{array}$ & 48.53 & 2.16 \\
\hline $\begin{array}{l}\text { Cement Mortar }(\mathrm{U}) \\
\text { Source } 1\end{array}$ & 28.00 & 38.22 \\
\hline $\begin{array}{l}\text { Lacquered Aluminium (WF) } \\
\text { Source } 3 / \text { Source } 2\end{array}$ & 359.36 & 34.60 \\
\hline
\end{tabular}

Data extracted from the BEDEC database (Source 1) [43], Doctoral Thesis: Mercader Moyano, Pilar (2010) Quantification of the resources consumed and $\mathrm{CO}_{2}$ emissions produced in the constructions of Andalusia and its implications in the Kyoto protocol—Doctoral thesis, U. Sevilla. (Source 2) [44] and from the CYPE Price Generator database (Source 3) [36].

It should be noted that none of the materials that make up the facade have recycled products. The products that make up the conventional facade, such as ceramic bricks, could contain recycled material; however, traditional bricks that are made from non-recycled raw material are still being chosen.

\section{Energy Performance of the Conventional Facade}

In order to analyze the energy performance of the building simulated with the conventional facade, each component is introduced in the LIDER/CALENER Unified Tool (HULC), Figure 9, which is the tool chosen for the development of this analysis.

First of all, the layers of the conventional facade are introduced in the 3D model. The components of this facade are detailed in Section 3.2. Conventional facade. The roof of the building is passable. It is composed of a unidirectional slab with concrete inter-beam and the outer layer is a concrete screed, and neither solution has insulation.

Once all the mandatory data have been inserted in the tool, the calculation is made to comply with the regulations of the Technical Building Code for Energy Saving. It is verified that the limit value for thermal transmittance or solar control is not met. This is due to the numerous shortcomings that the facade presents, such as the absence of insulation or the poor performance of the carpentry. A detailed study is carried out to know the energy gains and losses of the building. 


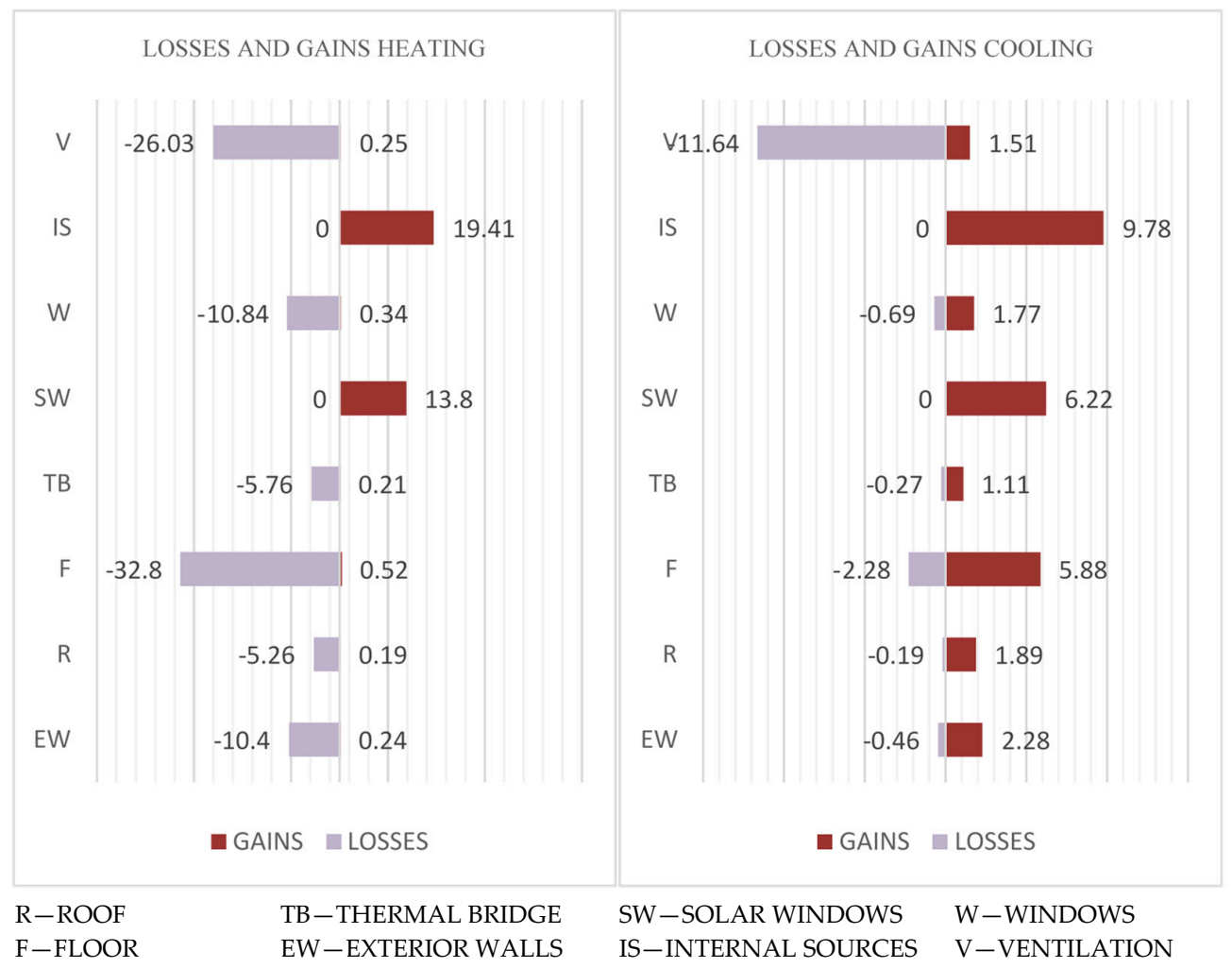

Figure 9. Distribution of gains and losses for heating with the conventional facade (left) and cooling (right). Extracted from the "LIDER-CALENER Unified Tool".

The total heating losses is $-88.50 \mathrm{kWh} / \mathrm{m}^{2}$.year. The facade has a loss of $-10.40 \mathrm{kWh} / \mathrm{m}^{2}$.year, this is equivalent to $12 \%$ of the total heating losses. Windows are a critical point on the facades of buildings, it is verified that the losses in this element are quite high. On the other hand, the gains in the facade are mainly attributed to the openings, with a $13.80 \mathrm{kWh} / \mathrm{m}^{2}$.year. With regard to cooling, the total losses are much lower, $-15.53 \mathrm{kWh} / \mathrm{m}^{2}$.year. Approximately $3 \%$ of the losses correspond to the exterior walls.

Therefore, it should be noted that both in cooling and heating the facades and openings are two determining elements. The chosen solution and the construction process of the same are of great importance to avoid, among others, thermal bridges.

\subsection{Prototype Facade for Rehabilitation}

The facade for building rehabilitation is made up of the conventional facade and new exterior layers. The prototype is made up of materials that have an Environmental Product Declaration (EPD) [45], Figure 10. For example, the window frame included has better performance than conventional lacquered aluminum carpentry.

Appendix A includes the calculations performed to obtain the data from the first two columns of the upper table. In the case of the components that make up the rehabilitated facade, they are specific materials whose energy consumption and $\mathrm{CO}_{2}$ emission values have been taken from the Environmental Product Declaration of the materials. The most unfavorable value of energy consumption is presented by window frame, with $85.00 \mathrm{MJ} / \mathrm{m}^{2}$, while in the case of $\mathrm{CO}_{2}$ emissions, it has a value of $2.30 \mathrm{kgCO}_{2} / \mathrm{m}^{2}$. On the other hand, thermal insulation consumes $57.17 \mathrm{MJ} / \mathrm{m}^{2}$ in its manufacturing process and emits $4.01 \mathrm{kgCO}_{2} / \mathrm{m}^{2}$. Finally, stone cladding has the lowest energy consumption and $\mathrm{CO}_{2}$ emissions values. 


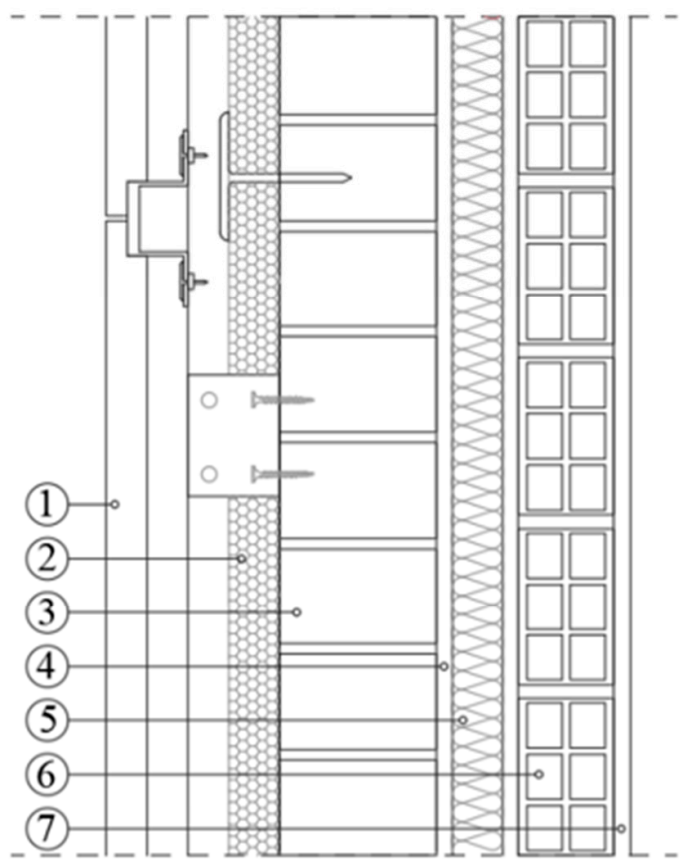

1. Exterior coating Capri stone cladding, $1200 \times 60 \times 4 \mathrm{~cm}$. Supported by an auxiliary structure made of aluminum.

2. Thermal insulation by semi-rigid rock wool panel. Thickness $37 \mathrm{~mm}$. Fixed to the main layer with metal screws.

3. Main layer made of waterproof perforated ceramic brick, $24 \times 11.5 \times 5 \mathrm{~cm}$, compressive strength $25 \mathrm{~N} / \mathrm{mm}^{2}$. Horizontal and vertical joints of $10 \mathrm{~mm}$ thick, received with industrial cement mortar M5 CEM II/A-L $32.5 \mathrm{~N}$.

4. Busbar layer composed of cement mortar M-2.5.

5 . Insulation by rigid polyurethane foam, $50 \mathrm{~mm}$ thick, 45 $\mathrm{kg} / \mathrm{m}^{3}$ density. $21 \times 11.5 \times 7 \mathrm{~cm}$.

6. Double hollow brick partition, compressive strength 5 $\mathrm{N} / \mathrm{mm}^{2}$.

7. Inner coating by means of a C6 thin-layer gypsum plaster on a previously lined surface.

\section{Windows frame of aluminum 75R by THECNAL.}

Figure 10. Section of prototype ventilated facade for rehabilitation. Own elaboration.

Table 3 shows the environmental impact generated by the elements that make up the façade for rehabilitation, while Table 4 shows the unified values of energy consumption and $\mathrm{CO}_{2}$ emissions extracted from Table 3. The highest values have been taken to propose the most unfavorable analysis with the aim of drawing relevant conclusions.

Table 3. Environmental impact generated by the elements that make up the facade for rehabilitation.

\begin{tabular}{|c|c|c|c|c|}
\hline Product & $\begin{array}{c}\text { Energy } \\
\text { Consumption } \\
\mathrm{MJ} / \mathrm{m}^{2}\end{array}$ & $\begin{array}{c}\mathrm{CO}_{2} \\
\text { Emissions } \\
\mathrm{KgCO}_{2} / \mathrm{m}^{2}\end{array}$ & $\begin{array}{c}\text { Energy } \\
\text { Consumption } \\
\mathrm{MJ} / \mathrm{m}^{2}\end{array}$ & $\begin{array}{c}\mathrm{CO}_{2} \\
\text { Emissions } \\
\mathrm{KgCO}_{2} / \mathrm{m}^{2}\end{array}$ \\
\hline $\begin{array}{l}\text { Stone cladding }\left(\mathrm{EC}^{1}\right) \\
\text { Source } 4 / \text { Source } 4\end{array}$ & 5.40 & 0.60 & 5.40 & 0.60 \\
\hline $\begin{array}{l}\text { Rock wool panel }\left(\mathrm{TI}^{2}\right) \\
\text { Source } 4 \text { /Source } 4\end{array}$ & 57.17 & 4.01 & 57.17 & 4.01 \\
\hline $\begin{array}{l}\text { Perforated Brick }\left(\mathrm{ML}^{3}\right) \\
\text { Source } 1 / \text { Source } 3\end{array}$ & 441.00 & 41.16 & 406.52 & 18.75 \\
\hline $\begin{array}{c}\text { Double Hollow Brick }\left(\mathrm{IL}^{4}\right) \\
\text { Source } 1 / \text { Source } 3\end{array}$ & 168.48 & 12.55 & 212.22 & 11.30 \\
\hline $\begin{array}{c}\text { Plaster Coating }\left(\mathrm{IC}^{5}\right) \\
\text { Source } 2 / \text { Source } 3\end{array}$ & 19.80 & 1.44 & 48.53 & 2.16 \\
\hline $\begin{array}{c}\text { Cement Mortar }\left(\mathrm{U}^{6}\right) \\
\text { Source } 1 / \text { Source } 3\end{array}$ & 28.00 & 38.22 & 13.05 & 1.01 \\
\hline $\begin{array}{c}\text { Aluminium C. } 75 \mathrm{R}\left(\mathrm{WF}^{7}\right) \\
\text { Source } 4 / \text { Source } 4\end{array}$ & 85.00 & 2.30 & 85.00 & 2.30 \\
\hline
\end{tabular}

${ }^{1}$ EC: Exterior Coating; ${ }^{2}$ TI: Thermal Insulation; ${ }^{3}$ ML: Main Layer; ${ }^{4}$ IL: Inner Layer; ${ }^{5}$ IC: Inner Coating, ${ }^{6}$ U: Unions; ${ }^{7}$ WF: Window frame. Data extracted from the BEDEC database (Source 1) [43], Doctoral Thesis: Mercader Moyano, Pilar (2010). Quantification of the resources consumed and $\mathrm{CO}_{2}$ emissions produced in the constructions of Andalusia and its implications in the Kyoto protocol-Doctoral thesis, U. Seville. (Source 2) [44] and from the CYPE Price Generator database (Source 3) [36] and Environmental Product Declaration (Source 4) [45]. 
Table 4. Unification of environmental impact values generated by the construction elements that make up the facade for rehabilitation.

\begin{tabular}{|c|c|c|}
\hline Product & $\begin{array}{l}\text { Energy Consumption } \\
\mathrm{MJ} / \mathrm{m}^{2}\end{array}$ & $\begin{array}{c}\mathrm{CO}_{2} \text { Emissions } \\
\mathrm{KgCO}_{2} / \mathrm{m}^{2}\end{array}$ \\
\hline $\begin{array}{l}\text { Stone cladding (EC) } \\
\text { Source } 4\end{array}$ & 5.40 & 0.60 \\
\hline $\begin{array}{l}\text { Rock wool panel (TI) } \\
\text { Source } 4\end{array}$ & 57.17 & 4.01 \\
\hline $\begin{array}{c}\text { Perforated Brick (ML) } \\
\text { Source } 1\end{array}$ & 441.00 & 41.16 \\
\hline $\begin{array}{l}\text { Double Hollow Brick (IL) } \\
\text { Source 3/Source } 1\end{array}$ & 212.22 & 12.55 \\
\hline $\begin{array}{c}\text { Plaster Coating (IC) } \\
\text { Source } 3\end{array}$ & 48.53 & 2.16 \\
\hline $\begin{array}{l}\text { Cement Mortar }(\mathrm{U}) \\
\text { Source } 1\end{array}$ & 28.00 & 38.22 \\
\hline $\begin{array}{c}\text { Aluminium C. } 75 \mathrm{R}(\mathrm{WF}) \\
\text { Source } 4\end{array}$ & 85.00 & 2.30 \\
\hline
\end{tabular}

Data extracted from the BEDEC database (Source 1) [43], Doctoral Thesis: Mercader Moyano, Pilar (2010) Quantification of the resources consumed and $\mathrm{CO}_{2}$ emissions produced in the constructions of Andalusia and its implications in the Kyoto protocol-Doctoral thesis, U. Seville. (Source 2) [44] and from the CYPE Price Generator database (Source 3) [36] and Environmental Product Declaration (Source 4) [45].

Finally, the percentage of recycled product contained in the elements that make up the facade for rehabilitation is analyzed. The values corresponding to the conventional façade are not included in the graph corresponding to Figure 11, since in all cases the percentage is zero.

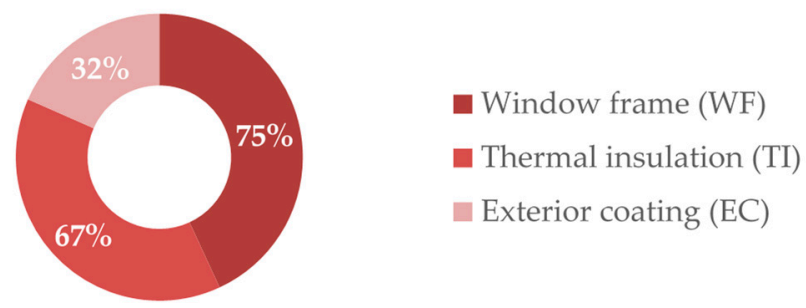

Figure 11. Percentage of recycled product from the materials that make up the rehabilitated facade.

Energy Performance of the Prototype Facade for Rehabilitation

In this section, the energy analysis of the building simulated in HULC is carried out. The energy performance of the building with the facade for rehabilitation is analyzed. This analysis allows us to observe the improvements that implies the implementation of the new designed facade.

The constructive characteristics of the components of the facade are introduced on LIDER-CALENER Unified Tool (HULC). On this occasion, the facade is improved as shown in Section 3.3. Prototype facade for rehabilitation.

The roof of the building is improved by adding thermal insulation and a waterproofing sheet. Thermal insulation is also placed on the existing pavement. The aluminum carpentry is replaced by a PVC with three chambers and double glass. With these changes made, numerous improvements are obtained, the building complies with current regulations, and it also reduces energy losses from the building.

The results obtained from the analysis in LIDER-CALENER Unified Tool (HULC) are shown graphically in Figure 12. 


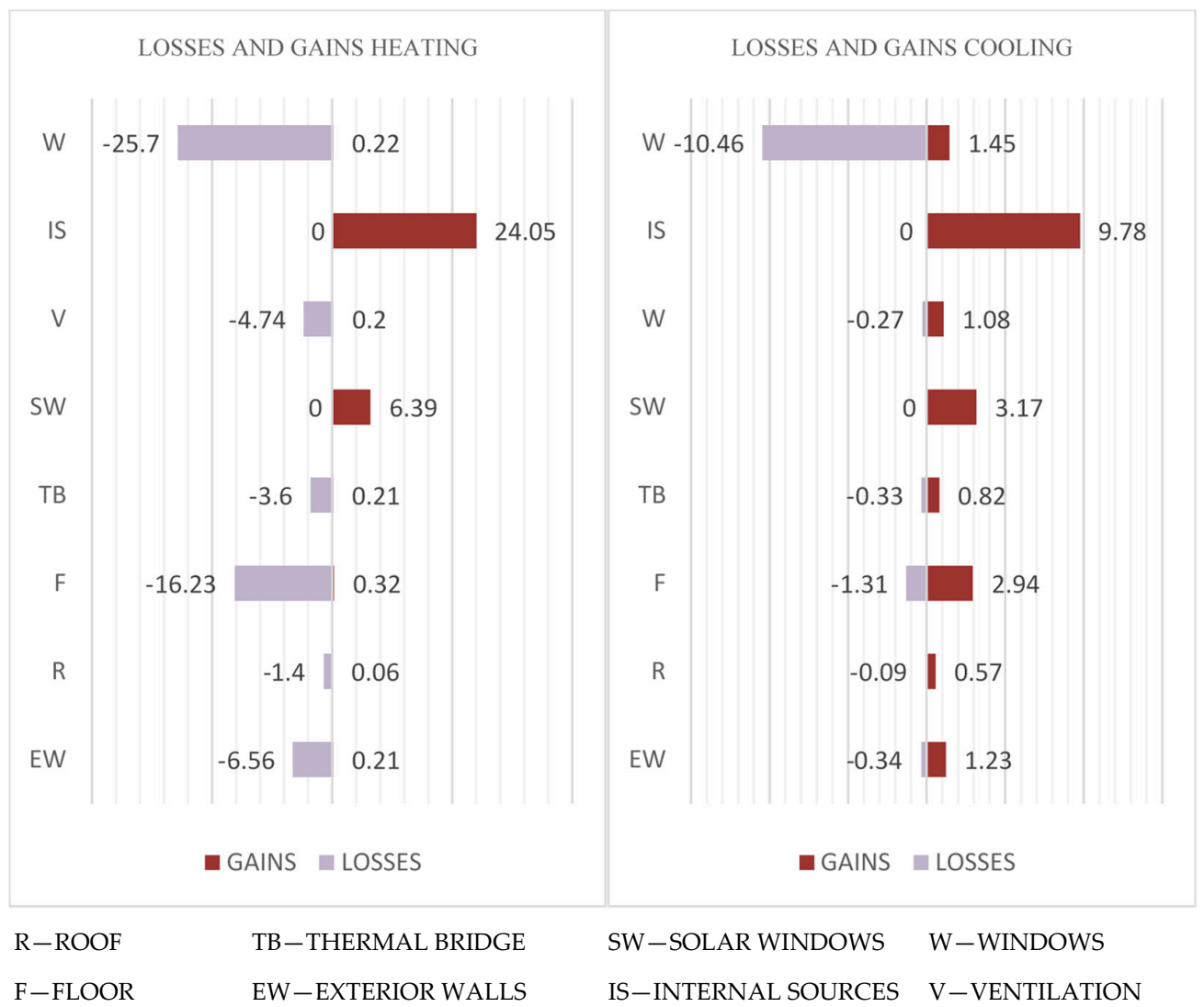

Figure 12. Distribution of gains and losses for heating with the rehabilitation facade (left) and cooling (right). Extracted from the "LIDER-CALENER Unified Tool".

The data obtained referring to energy gains and losses shows that total heating losses decrease to $-66.73 \mathrm{kWh} / \mathrm{m}^{2}$.year with the improvements made in the building. Of this total, around $10 \%\left(-6.56 \mathrm{kWh} / \mathrm{m}^{2}\right.$.year) corresponds to the facade. At the same time that the total gains become $31.65 \mathrm{kWh} / \mathrm{m}^{2}$ year, $20 \%$ of these gains correspond to the windows, with a value of $6.39 \mathrm{kWh} / \mathrm{m}^{2}$.year. With regard to refrigeration, the total losses fall to a value of $-12.81 \mathrm{kWh} / \mathrm{m}^{2}$.year, and only around $3 \%$ corresponds to the facade.

\section{Results and Discussion}

This section examines the characteristics of the materials that make up the two facades to be studied. The energy consumption and $\mathrm{CO}_{2}$ emissions of each of their components are determined, as well as the total per square meter of facade. In addition to the percentage of recycled product that exists on each facade. After this, the losses produced by heating and cooling in each member of the envelope are compared, from floors, roofs, to thermal bridges. This supposes a complete analysis of the energetic behavior of the building

\subsection{Analysis of the Eco-Efficient Characteristics of the Facade Materials}

A comparison is made between the facades from the point of view of sustainability and eco-efficiency in order to ensure that the rehabilitation proposal involves environmental improvements compared to the conventional façade, you can see in Figure 13. 


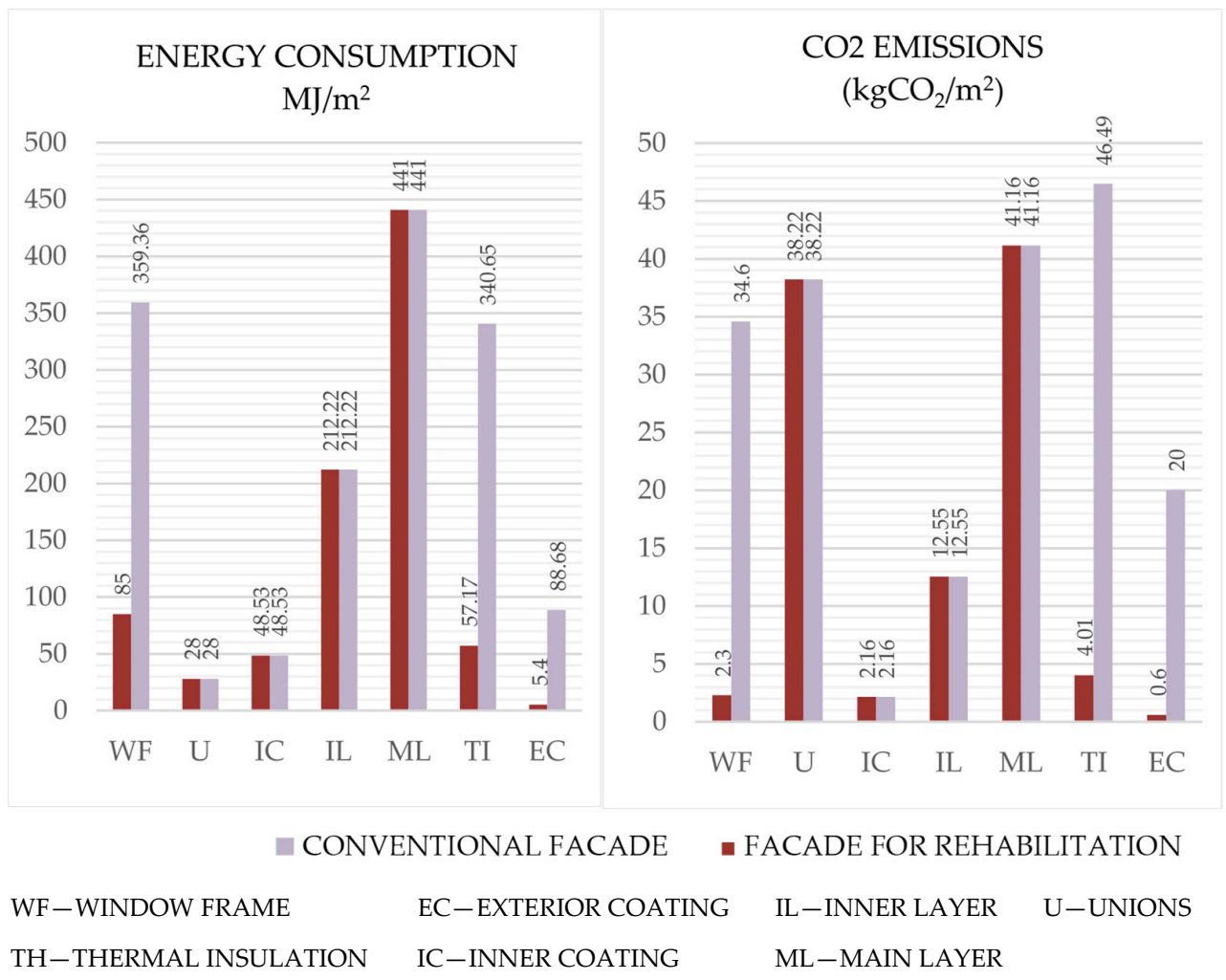

Figure 13. Energy incorporated per square meter of the materials that make up the facades (left) and $\mathrm{CO}_{2}$ emissions per square meter of the materials that make up the facades (right).

Regarding energy consumption, we observe that there are great differences between some elements, specifically, between thermal insulation and window frame. In the case of thermal insulation, the energy consumption of the insulation used in the rehabilitation façade is $283.48 \mathrm{MJ} / \mathrm{m}^{2}$ lower than that used in the conventional façade. This is a great energy improvement. Similarly, the window frame used in the rehabilitation proposal has a lower energy consumption than that used in the conventional one, the difference being $274.36 \mathrm{MJ} / \mathrm{m}^{2}$.

Analyzing $\mathrm{CO}_{2}$ emission values, the window frame of the rehabilitated facade emits $31.70 \mathrm{kgCO}_{2} / \mathrm{m}^{2}$ less than that the one used in the conventional facade. In the case of thermal insulation, the difference is even greater, as said difference is $42.48 \mathrm{kgCO}_{2} / \mathrm{m}^{2}$. Similarly, analyzing the exterior cladding, it is found that the difference is also notable, as said difference is $19.40 \mathrm{kgCO} / \mathrm{m}^{2}$.

Once the above has been exposed, two bar graphs are made and analyzed in which the total values of the indices analyzed on the two facades are represented. These indices are: The total energy consumption of each facade per square meter, the total $\mathrm{CO}_{2}$ emissions of each facade per square meter, and the average percentage of recycled product contained in the materials that make up the facades analyzed, you can see in Figure 14. 


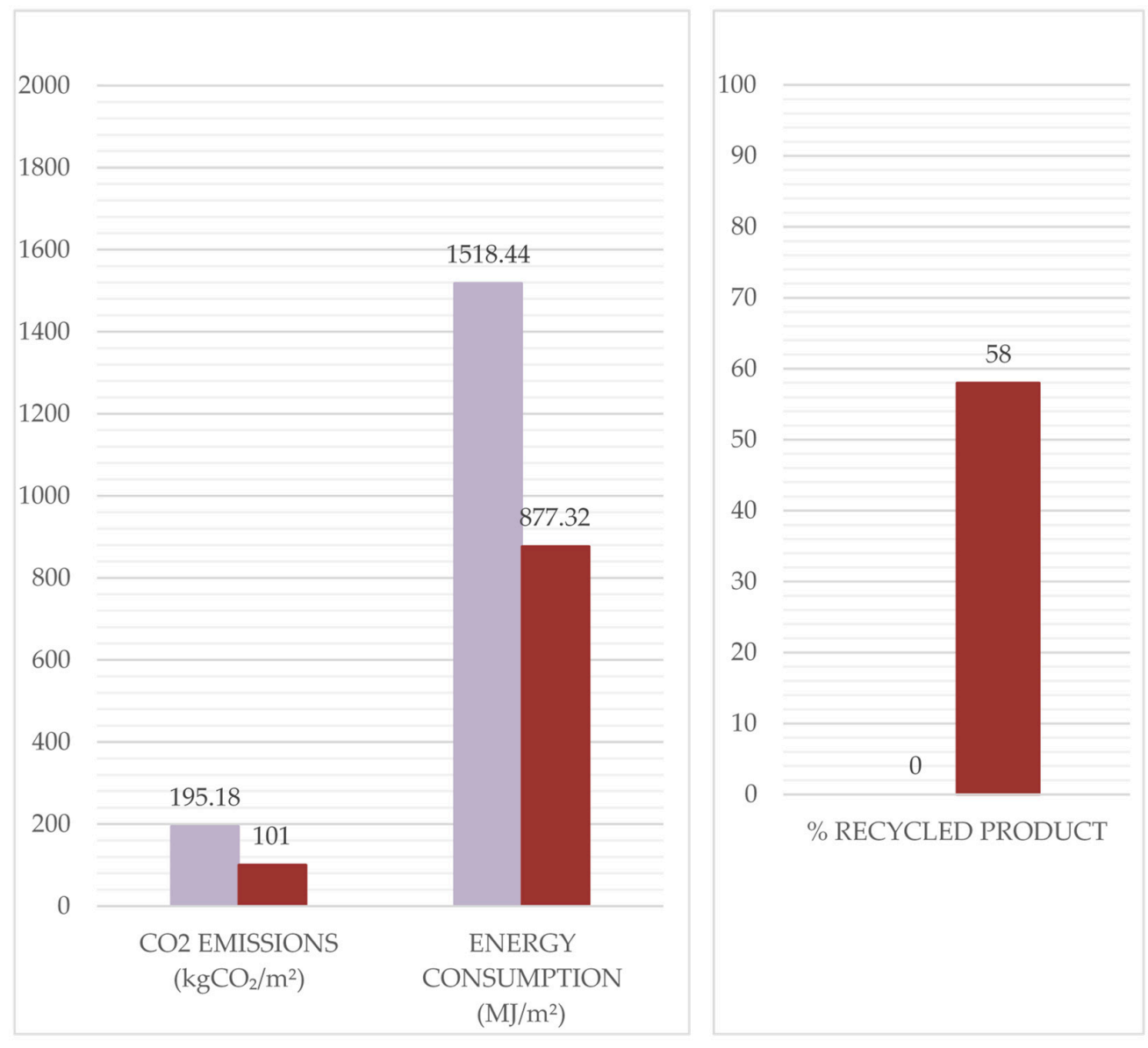

-CONVENTIONAL FACADE $\quad$ FACADE FOR REHABILITATION

Figure 14. Total values of energy consumption and $\mathrm{CO}_{2}$ emissions per square meter (left) and percentage values of recycled product of the materials that make up the facades (right).

In the case of energy consumption values and $\mathrm{CO}_{2}$ emissions, the designed facade presents the most favorable values. The proposed facade consumes $641.12 \mathrm{MJ} / \mathrm{m}^{2}$ less than the conventional facade. The conventional facade requires a total of $1518.44 \mathrm{MJ} / \mathrm{m}^{2}$ to be made and the facade for rehabilitation consumes a total of $877.32 \mathrm{MJ} / \mathrm{m}^{2}$ in its fabrication process. It is assumed that the prototype facade requires approximately $35 \%$ less energy than the conventional facade analyzed for its manufacture.

With regard to $\mathrm{CO}_{2}$ emissions, the difference in the values of the facades is less than in the case of energy consumption. The total difference is $94.18 \mathrm{kgCO}_{2} / \mathrm{m}^{2}$, with lower emissions from the facade for rehabilitation.

Analyzing the average percentage of recycled material contained in the products that make up the facades, once again the rehabilitation proposal presents more favorable values. This is due to the fact that it has an average percentage of recycled product of $58 \%$ compared to $0 \%$ that the conventional facade presents.

\subsection{Comparative Analysis of the Energy Performance of Facades}

After studying the energy performance of the building model with a conventional solution and with the facade for rehabilitation, a comparison is performed to verify that the proposed facade has a favorable effect on the comfort conditions of the building.

The comparison analyzes the heating and cooling losses since they are more relevant than the gains and have a greater global impact in the energy study, Figure 15. 


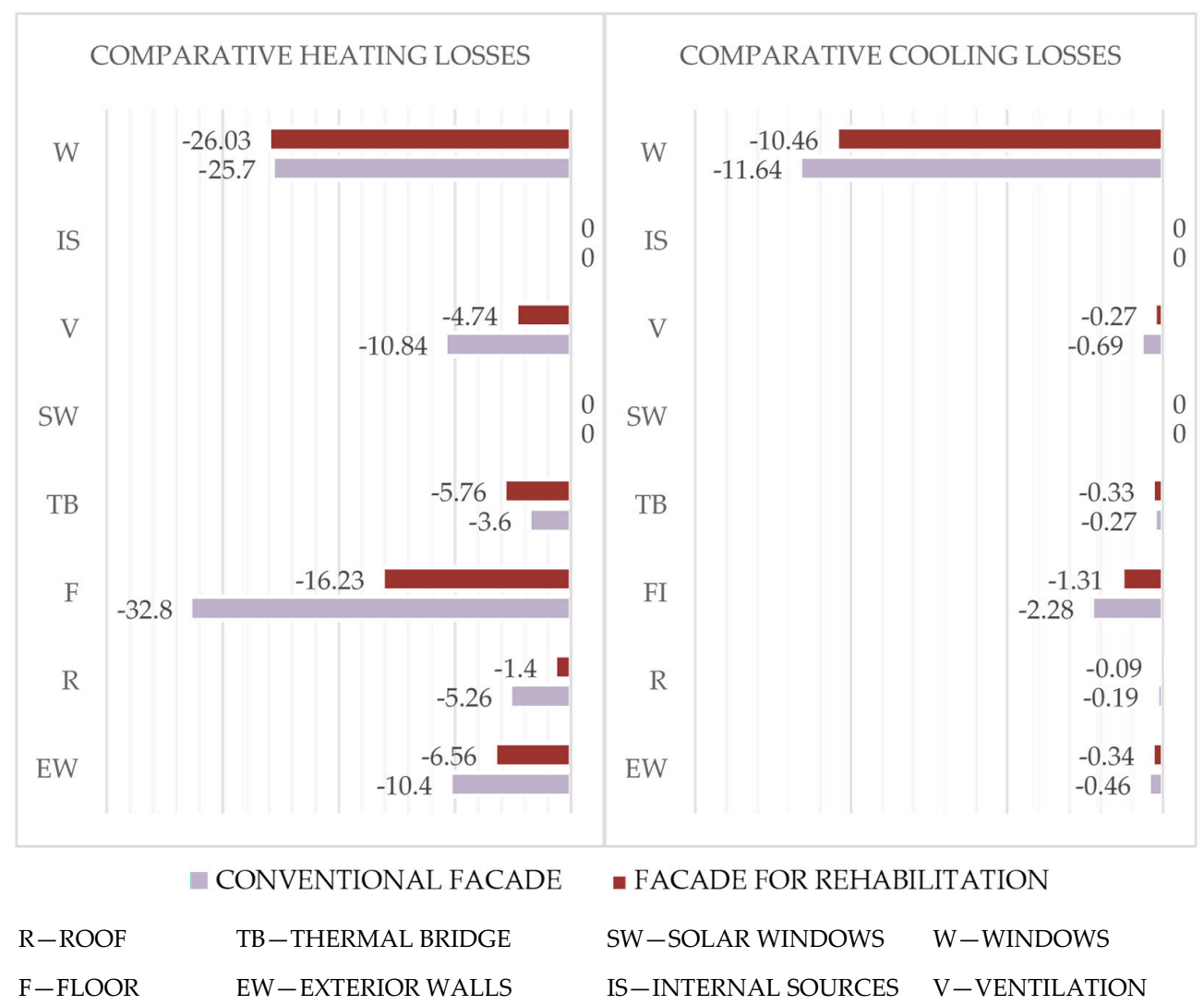

Figure 15. Comparison of losses due to heating (left) and cooling (right) of the conventional and the rehabilitated solution. Extracted from the "LIDER-CALENER Unified Tool".

Total heating losses go from $-88.50 \mathrm{kWh} / \mathrm{m}^{2}$.year to $-60.73 \mathrm{kWh} / \mathrm{m}^{2}$.year, annual losses during cold months are reduced by $32 \%$. This means a great saving of energy used to heat the home, since the demand for it is also reduced. This also implies a reduction in the economic cost, derived from the improvements made to the building. Regarding cooling losses, the variation is less than those of heating. The total annual values go from $-15.53 \mathrm{kWh} / \mathrm{m}^{2}$.year to $-12.81 \mathrm{kWh} / \mathrm{m}^{2}$.year $\cdot$ year. The total reduction is approximately $18 \%$.

\section{Conclusions}

To summarize, it can be said that the construction sector is a great incentive to the process of climate change. This is due to the large volume of industry that the sector requires to carry out its activities. In addition, the production and manufacturing processes, necessary for the generation of construction materials, involve high energy costs. So, it is necessary to include concepts of eco-efficiency and sustainability in the world of architecture and construction that reduce energy costs. Similarly, it is essential to promote projects in which aspects aimed at improving the sector are investigated and promoted from the point of view of sustainability. Of course, proposing a circular production model in the construction sector would mean considerable improvements for the current state of the planet.

It is verified that the facade for rehabilitation reduces energy consumption and $\mathrm{CO}_{2}$ emissions with respect to the conventional facade. The reduction in energy consumption between the conventional facade and the rehabilitated one represents more than $57 \%$ and $\mathrm{CO}_{2}$ emissions fall by $51 \%$. This is due to the fact that materials whose environmental impact is low are used for the configuration of the facade for rehabilitation.

The implementation of techniques to carry out the analysis of the different construction solutions chosen, allows knowing and evaluating the situation in which the model building 
is at an energy level. It also makes it possible to quantify energy gains and losses through the conventional façade and the façade for rehabilitation.

In addition, rehabilitation has made it possible to assess the potential for improvement in indoor environmental quality and reducing energy demand for housing. This makes an improvement in habitability and a reduction in environmental impact. All of this is possible thanks to the facade that is developed in the project.

The rehabilitation of the model building reduces the energy losses of the building, heating losses are reduced by $32 \%$, and cooling losses by $18 \%$. This is a very positive fact due to it producing a lower demand for energy from air conditioning systems. In addition, it beneficially affects energy consumption and its economic cost. It is concluded that the facade is a major contributor to energy gains and losses in cooling and heating.

Finally, the sustainable architecture concepts developed in this project are not limited to the implementation of eco-efficient facades for rehabilitation. These ideas can be applied to the design and manufacture of other construction elements such as roofs.

It is also important to mention that other types of materials and techniques can be used to manufacture construction elements in order to provide additional benefits in terms of energy consumption. In this way, the guidelines proposed in this project can give rise to new branches of architecture that are more environmentally friendly. They can also facilitate its integration into the circular economy paradigm, potentially reducing the environmental and economic impact of architecture.

Author Contributions: Conceptualization, A.R.-C., P.A.-D. and P.M.-M.; Methodology, A.R.-C., P.A.-D. and P.M.-M.; Validation, A.R.-C., P.A.-D. and P.M.-M.; Formal analysis, A.R.-C. and P.A.-D.; Investigation, A.R.-C., P.A.-D. and P.M.-M.; Resources, A.R.-C. and P.A.-D.; Data curation, A.R.-C., P.A.-D. and P.M.-M.; Writing-original draft preparation, A.R.-C., P.A.-D. and P.M.-M.; Writingreview and editing, A.R.-C., P.A.-D. and P.M.-M.; Visualization, A.R.-C. and P.A.-D.; Supervision, P.M.-M.; Project administration, P.M.-M.; Funding acquisition, P.M.-M. All authors have read and agreed to the published version of the manuscript.

Funding: This research has been funded by the research project art. 68/83 LOU ref. 4115/0632 thanks to GRUPO PUMA S.L Y PROARID GREEN S.L. The results of this work apply the knowledge acquired during the research stay at the Secretary of Postgraduate of the Faculty of Architecture and Urbanism and also in the Experimental Centre of Production, University of Buenos Aires, Argentina, which was improved in the research stay at the National University of La Plata, Argentina, developed by the first author of the article and the results are the same. These results have been included and are part of a final degree research project in architecture carried out by the second and the third author and directed by the first author; so it represents the transfer of knowledge acquired in the University of Buenos Aires, Argentina, in the field work carried out in-situ in Spain.

Institutional Review Board Statement: Not applicable.

Informed Consent Statement: Not applicable.

Data Availability Statement: The data collected are original and specific to the research and have not been previously published.

Conflicts of Interest: The authors declare no conflict of interest.

\section{Appendix A. Calculation of Energy Consumption and $\mathrm{CO}_{2}$ Emissions of Materials} Appendix A.1. Calculation Methodology

In this appendix, the necessary calculations are carried out in detail to obtain the values of energy consumption and $\mathrm{CO}_{2}$ emissions of the materials that make up each of the facades for each square meter.

To carry out the calculations, three fundamental values will be necessary: The energy consumption per kilogram of each material $(\mathrm{MJ} / \mathrm{kg})$, the kilograms of $\mathrm{CO}_{2}$ generated in the manufacturing process for each kilogram $\left(\mathrm{kgCO}_{2} / \mathrm{kg}\right)$, and the density or specific weight of materials $\left(\mathrm{kg} / \mathrm{m}^{3}\right)$. 
First of all, it is necessary to know the kilograms of material that are in each square meter of facade. To do this, the density of the material is multiplied by the height, width, and thickness of the material. In this case, the height and width are one meter, which is why the density value is multiplied by the thickness of the material.

Weight $=$ Density $\left(\mathrm{kg} / \mathrm{m}^{3}\right) \cdot$ Height $(1 \mathrm{~m}) \cdot$ Width $(1 \mathrm{~m}) \cdot$ Thickness (meters)

To calculate the energy consumption per square meter of facade, it is necessary to multiply the Weight $(\mathrm{kg})$ by the energy consumption $(\mathrm{MJ} / \mathrm{kg})$.

Energy consumption per $\mathrm{m}^{2}=$ Weight $(\mathrm{kg}) \cdot$ Consumption per kilogram $(\mathrm{MJ} / \mathrm{kg})$

To calculate $\mathrm{CO}_{2}$ emissions per square meter of enclosure, it is necessary to multiply the Weight $(\mathrm{kg})$ by the kilograms of $\mathrm{CO}_{2}$ that are emitted for each kilogram of material in the manufacturing process.

$\mathrm{CO}_{2}$ emissions per $\mathrm{m}^{2}=$ Weight $(\mathrm{kg}) \cdot \mathrm{CO}_{2}$ emissions per kilogram $\left(\mathrm{kgCO}_{2} / \mathrm{kg}\right)$

\section{Appendix A.2. Obtaining Fundamental Values for the Calculation}

It is necessary to know the values of energy consumption and $\mathrm{CO}_{2}$ emissions for each kilogram of material to calculate the value of energy consumption and $\mathrm{CO}_{2}$ emissions per meter square. It is also necessary to know the density of each material. These values have been obtained from the following sources:

- Source 1_Database: Banco Estructurado de Elementos Constructivos (BEDEC). Database prepared by the Technical Institute of Construction of Catalonia (iTeC) [43].

- $\quad$ Source 2_Doctoral Thesis: Mercader Moyano, Pilar (2010). Quantification of the resources consumed and $\mathrm{CO}_{2}$ emissions produced in the constructions of Andalusia and its implications in the Kyoto protocol-Doctoral thesis, University of Sevilla [44].

- Source 3_Certification: Environmental Product Declarations (EPD) extracted from AENOR. The products that made up the rehabilitation facade has this certification [45].

Table A1. Energy consumption and $\mathrm{CO}_{2}$ emissions per kilogram and density of the construction materials that make up the facades analyzed.

\begin{tabular}{|c|c|c|c|c|}
\hline Product & Source & $\begin{array}{c}\text { Energy } \\
\text { Consumption } \\
\mathrm{MJ} / \mathrm{kg}\end{array}$ & $\begin{array}{c}\mathrm{CO}_{2} \\
\text { Emissions } \\
\mathrm{KgCO}_{2} / \mathrm{kg}\end{array}$ & $\begin{array}{c}\text { Specific } \\
\text { Density } \\
\mathrm{Kg} / \mathrm{m}^{3}\end{array}$ \\
\hline Natural Stone (EC) & $2[44]$ & 0.32 & 0.50 & 2000.00 \\
\hline Stone Cladding (EC) & $3[45]$ & 0.18 & 0.02 & 1500.00 \\
\hline Perforated Brick (ML) & $1[43]$ & 4.50 & 0.42 & 1400.00 \\
\hline Double Hollow Brick (IL) & $1[43]$ & 4.16 & 0.31 & 810.00 \\
\hline Plaster Coating (IC) & $2[44]$ & 3.30 & 0.24 & 600.00 \\
\hline Cement Mortar (U) & $1[43]$ & 7.00 & 1.82 & 1400.00 \\
\hline Polyurethane Foam (TI) & $2[44]$ & 140.00 & 20.66 & 45.00 \\
\hline Rock wool panel (TI) & $3[45]$ & 51.50 & 3.61 & 30.00 \\
\hline Lacquered Aluminium (WF) & $2[44]$ & 218.00 & 32.05 & 2700.00 \\
\hline Aluminium C. 75 R (WF) & $3[45]$ & 85.00 & 2.3 & 2500.00 \\
\hline
\end{tabular}

Appendix A.3. Calculation of Energy Constumption and $\mathrm{CO}_{2}$ Emissions

Natural Stone (EC-Exterior Coating)

Weight $=2.000 \mathrm{~kg} / \mathrm{m}^{3} \cdot 1 \mathrm{~m} \cdot 1 \mathrm{~m} \cdot 0.02 \mathrm{~m}=40 \mathrm{~kg}$

Energy consumption per $\mathrm{m}^{2}=40 \mathrm{~kg} \cdot 0.32 \mathrm{MJ} / \mathrm{kg}=12.80 \mathrm{MJ} / \mathrm{m}^{2}$

$\mathrm{CO}_{2}$ emissions per $\mathrm{m}^{2}=40 \mathrm{~kg} \cdot 0.50 \mathrm{KgCO}_{2} / \mathrm{kg}=20 \mathrm{kgCO} / \mathrm{m}^{2}$

Stone Cladding (EC-Exterior Coating)

Weight $=1500 \mathrm{~kg} / \mathrm{m}^{3} \cdot 1 \mathrm{~m} \cdot 1 \mathrm{~m} \cdot 0.02 \mathrm{~m}=30 \mathrm{~kg}$

Energy consumption per $\mathrm{m}^{2}=30 \mathrm{~kg} \cdot 0.18 \mathrm{MJ} / \mathrm{kg}=5.40 \mathrm{MJ} / \mathrm{m}^{2}$

$\mathrm{CO}_{2}$ emissions per $\mathrm{m}^{2}=30 \mathrm{~kg} \cdot 0.02 \mathrm{KgCO}_{2} / \mathrm{kg}=0.60 \mathrm{kgCO}_{2} / \mathrm{m}^{2}$

Perforated Brick (ML-Main Layer) 
Weight $=1400 \mathrm{~kg} / \mathrm{m}^{3} \cdot 1 \mathrm{~m} \cdot 1 \mathrm{~m} \cdot 0.07 \mathrm{~m}=98 \mathrm{~kg}$

Energy consumption per $\mathrm{m}^{2}=98 \mathrm{~kg} \cdot 4.50 \mathrm{MJ} / \mathrm{kg}=441 \mathrm{MJ} / \mathrm{m}^{2}$

$\mathrm{CO}_{2}$ emissions per $\mathrm{m}^{2}=98 \mathrm{~kg} \cdot 0.42 \mathrm{KgCO}_{2} / \mathrm{kg}=41.16 \mathrm{kgCO}_{2} / \mathrm{m}^{2}$

Double Hollow Brick (IL-Inner Layer)

Weight $=810 \mathrm{~kg} / \mathrm{m}^{3} \cdot 1 \mathrm{~m} \cdot 1 \mathrm{~m} \cdot 0.05 \mathrm{~m}=40.50 \mathrm{~kg}$

Energy consumption per $\mathrm{m}^{2}=40.50 \mathrm{~kg} \cdot 4.16 \mathrm{MJ} / \mathrm{kg}=168.48 \mathrm{MJ} / \mathrm{m}^{2}$

$\mathrm{CO}_{2}$ emissions per $\mathrm{m}^{2}=40.50 \mathrm{~kg} \cdot 0.31 \mathrm{KgCO}_{2} / \mathrm{kg}=12.55 \mathrm{kgCO}_{2} / \mathrm{m}^{2}$

Plaster Coating (IC-Inner Coating)

Weight $=600 \mathrm{~kg} / \mathrm{m}^{3} \cdot 1 \mathrm{~m} \cdot 1 \mathrm{~m} \cdot 0.01 \mathrm{~m}=6 \mathrm{~kg}$

Energy consumption per $\mathrm{m}^{2}=6 \mathrm{~kg} \cdot 3.30 \mathrm{MJ} / \mathrm{kg}=19.80 \mathrm{MJ} / \mathrm{m}^{2}$

$\mathrm{CO}_{2}$ emissions per $\mathrm{m}^{2}=6 \mathrm{~kg} \cdot 0.24 \mathrm{KgCO}_{2} / \mathrm{kg}=1.44 \mathrm{kgCO}_{2} / \mathrm{m}^{2}$

Cement Mortar (U-Unions)

Weight $=1400 \mathrm{~kg} / \mathrm{m}^{3} \cdot 1 \mathrm{~m} \cdot 1 \mathrm{~m} \cdot 0.015 \mathrm{~m}=21 \mathrm{~kg}$

Energy consumption per $\mathrm{m}^{2}=21 \mathrm{~kg} \cdot 7 \mathrm{MJ} / \mathrm{kg}=28 \mathrm{MJ} / \mathrm{m}^{2}$

$\mathrm{CO}_{2}$ emissions per $\mathrm{m}^{2}=21 \mathrm{~kg} \cdot 1.82 \mathrm{KgCO}_{2} / \mathrm{kg}=38.22 \mathrm{kgCO}_{2} / \mathrm{m}^{2}$

Polyurethane Foam (TI-Thermal Insulation)

Weight $=45 \mathrm{~kg} / \mathrm{m}^{3} \cdot 1 \mathrm{~m} \cdot 1 \mathrm{~m} \cdot 0.05 \mathrm{~m}=2.25 \mathrm{~kg}$

Energy consumption per $\mathrm{m}^{2}=2.25 \mathrm{~kg} \cdot 140 \mathrm{MJ} / \mathrm{kg}=315 \mathrm{MJ} / \mathrm{m}^{2}$

$\mathrm{CO}_{2}$ emissions per $\mathrm{m}^{2}=2.25 \mathrm{~kg} \cdot 20.66 \mathrm{KgCO}_{2} / \mathrm{kg}=46.49 \mathrm{kgCO}_{2} / \mathrm{m}^{2}$

Rock wool panel (TI-Thermal Insulation)

Weight $=30 \mathrm{~kg} / \mathrm{m}^{3} \cdot 1 \mathrm{~m} \cdot 1 \mathrm{~m} \cdot 0.037 \mathrm{~m}=1.11 \mathrm{~kg}$

Energy consumption per $\mathrm{m}^{2}=1.11 \mathrm{~kg} \cdot 51.50 \mathrm{MJ} / \mathrm{kg}=57.17 \mathrm{MJ} / \mathrm{m}^{2}$

$\mathrm{CO}_{2}$ emissions per m $\mathrm{m}^{2}=1.11 \mathrm{~kg} \cdot 3.61 \mathrm{KgCO}_{2} / \mathrm{kg}=4.01 \mathrm{kgCO}_{2} / \mathrm{m}^{2}$

In the case of window frame an approximation is made, since in a square meter of envelope there is approximately $20 \%$ aluminum, so this percentage is applied to energy consumption and $\mathrm{CO}_{2}$ emissions.

Lacquered Aluminium (WF-Window Frame)

Weight $=2700 \mathrm{~kg} / \mathrm{m}^{3} \cdot 1 \mathrm{~m} \cdot 1 \mathrm{~m} \cdot 0.002 \mathrm{~m}=5.40 \mathrm{~kg}$

Energy consumption per $\mathrm{m}^{2}=5.40 \mathrm{~kg} \cdot 218 \mathrm{MJ} / \mathrm{kg}=1177.20 \mathrm{MJ} / \mathrm{m}^{2}$

$20 \%\left(1177.20 \mathrm{MJ} / \mathrm{m}^{2}\right)=235.44 \mathrm{MJ} / \mathrm{m}^{2}$

$\mathrm{CO}_{2}$ emissions per m${ }^{2} 2=5.40 \mathrm{~kg} \cdot 32.05 \mathrm{KgCO}_{2} / \mathrm{kg}=173.07 \mathrm{kgCO}_{2} / \mathrm{m}^{2}$

$20 \%\left(1730.70 \mathrm{MJ} / \mathrm{m}^{2}\right)=34.60 \mathrm{kgCO} / \mathrm{m}^{2}$

Aluminium CIRCAL $75 \mathrm{R}$ (WF-Window Frame)

Weight $=2500 \mathrm{~kg} / \mathrm{m}^{3} \cdot 1 \mathrm{~m} \cdot 1 \mathrm{~m} \cdot 0.002 \mathrm{~m}=5 \mathrm{~kg}$

Energy consumption per $\mathrm{m}^{2}=5 \mathrm{~kg} \cdot 85 \mathrm{MJ} / \mathrm{kg}=425 / \mathrm{m}^{2} 20 \%\left(425 \mathrm{MJ} / \mathrm{m}^{2}\right)=85 \mathrm{MJ} / \mathrm{m}^{2}$

$\mathrm{CO}_{2}$ emissions per $\mathrm{m}^{2}=5 \mathrm{~kg} \cdot 2.30 \mathrm{KgCO}_{2} / \mathrm{kg}=11.50 \mathrm{kgCO} / \mathrm{m}^{2} 20 \%$ $\left(11.50 \mathrm{MJ} / \mathrm{m}^{2}\right)=\mathrm{kgCO} 2 / \mathrm{m}^{2}$

\section{References}

1. Colangelo, F.; De Luca, G.; Ferone, C.; Mauro, A. Experimental and Numerical Analysis of Thermal and Hygrometric Characteristics of Building Structures Employing Recycled Plastic Aggregates and Geopolymer Concrete. Energies 2013, 6, 6077-6101. [CrossRef]

2. EUROSTAT-European Commission-European Statistical Office. Available online: https://ec.europa.eu/eurostat/tgm/table. do?tab=table\&init=1\&language $=$ en\&pcode=tec00001\&plugin $=1$ (accessed on 25 September 2021).

3. CEPALASTAT-Economic Commission for Latin America and the Caribbean. Available online: https:/ /estadisticas.cepal.org/ cepalstat/PerfilesNacionales.html?idioma=spanish (accessed on 25 September 2021).

4. Kalinović, S.M.; Tanikić, D.I.; Djoković, J.M.; Nikolić, R.R.; Hadzima, B.; Ulewicz, R. Optimal Solution for an Energy Efficient Construction of a Ventilated Façade Obtained by a Genetic Algorithm. Energies 2021, 14, 3293. [CrossRef] 
5. International Energy Agency (IEA). Available online: https://www.iea.org/ (accessed on 25 September 2021).

6. Environmental European Agency (EEA). Available online: https://www.eea.europa.eu/es (accessed on 25 September 2021).

7. European Commission. Europe 2020. A Strategy for Smart, Sustainable and Inclusive Growth. COM, 2010. Available online: https:/ / eur-lex.europa.eu/LexUriServ/LexUriServ.do?uri=COM:2010:2020:FIN:EN:PDF (accessed on 25 September 2021).

8. European Commission. Communication from the Commission to the European Parliament, the Council, the European Economic and Social Committee and the Committee of the Regions. Closing the Loop: An EU Action Plan for the Circular Economy. COM, 2015. Available online: https:/ / ec.europa.eu/transparency/regdoc/rep/1/2015/ES/1-2015-614-ES-F1-1.PDF (accessed on 25 September 2021).

9. European Commission. Communication from the Commission Ecodesign Working Plan. COM, 2016. Available online: https:/ / eur-lex.europa.eu/legal-content/EN/TXT/PDF/?uri=CELEX:52016DC0773\&from=EN (accessed on 25 September 2021).

10. European Commission. Report from the Commission to the European Parliament, the Council, the European Economic and Social Committee and the Committee of the Regions. On the Implementation of the Action Plan for the Circular Economy. COM, 2017. Available online: https:/ / ec.europa.eu/transparency/regdoc/rep/1/2017/ES/COM-2017-33-F1-ES-MAIN-PART-1.PDF (accessed on 25 September 2021).

11. European Commission. Report from the Commission to the European Parliament, the Council, the European Economic and Social Committee and the Committee of the Regions. On the Implementation of the Action Plan for the Circular Economy. COM, 2019. Available online: https:/ / eurlex.europa.eu/legalcontent/ES/TXT/PDF/?uri=CELEX:52019DC0190\&from=EN (accessed on 25 September 2021).

12. LourençO, J.M.; Aelenei, L.; Facão, J.; Gonçalves, H.; Aelenei, D.; Pina, J.M. The Use of Key Enabling Technologies in the Nearly Zero Energy Buildings Monitoring, Control and Intelligent Management. Energies 2021, 14, 5524. [CrossRef]

13. Resende, J.; Corvacho, H. The nZEB Requirements for Residential Buildings: An Analysis of Thermal Comfort and Actual Energy Needs in Portuguese Climate. Sustainability 2021, 13, 8277. [CrossRef]

14. Mercader-Moyano, P.; Esquivias, P.M. Decarbonization and Circular Economy in the Sustainable Development and Renovation of Buildings and Neighbourhoods. Sustainability 2020, 12, 7914. [CrossRef]

15. Sukamto, D.; Siroux, M.; Gloriant, F. Hot Box Investigations of a Ventilated Bioclimatic Wall for NZEB Building Façade. Energies 2021, 14, 1327. [CrossRef]

16. Pastori, S.; Mereu, R.; Mazzucchelli, E.S.; Passoni, S.; Dotelli, G. Energy Performance Evaluation of a Ventilated Façade System through CFD Modeling and Comparison with International Standards. Energies 2021, 14, 193. [CrossRef]

17. Shameri, M.A.; Alghoul, M.A.; Sopian, K.; Fauzi, M.; Zain, M.; Elayeb, O. Perspectives of double skin façade systems in buildings and energy saving. Renew. Sustain. Energy Rev. 2011, 15, 1468-1475. [CrossRef]

18. Kim, S.; Zirkelbach, D.; Künzel, H.M.; Lee, J.H.; Choi, J. Development of test reference year using ISO 15927-4 and the influence of climatic parameters on building energy performance. Build. Environ. 2017, 114, 374-386. [CrossRef]

19. Bilous, I.; Deshko, V.; Sukhodub, I. Parametric analysis of external and internal factors influence on building energy performance using non-linear multivariate regression models. J. Build. Eng. 2018, 20, 327-336. [CrossRef]

20. Pajek, L.; Košir, M. Can building energy performance be predicted by a bioclimatic potential analysis? Case study of the Alpine-Adriatic region. Energy Build. 2017, 139, 160-173. [CrossRef]

21. Camacho, C.R. Study of Footprints in the Life Cycle of the Residential Building. Universidad de Sevilla. Available online: https:/ /idus.us.es/handle/11441/102354 (accessed on 25 September 2021).

22. León, Á.L.; Domínguez, S.; Campano, M.A.; Ramírez-Balas, C. Reducing the Energy Demand of Multi-Dwelling Units in a Mediterranean Climate Using Solar Protection Elements. Energies 2012, 5, 3398-3424. [CrossRef]

23. Valentín, D.; Guardo, A.; Egusquiza, E.; Valero, C.; Alavedra, P. Assessment of the Economic and Environmental Impact of Double Glazed Façade Ventilation Systems in Mediterranean Climates. Energies 2013, 6, 5069-5087. [CrossRef]

24. Escandón, R.; Suárez, R.; Sendra, J.J. Protocol for the Energy Behaviour Assessment of Social Housing Stock: The Case of Southern Europe. Energy Procedia 2016, 96, 907-915. [CrossRef]

25. Gobierno de España, Ministerio de Agricultura y Pesca, Alimentación y Medioambiente. Pacto por una Economía Circular: El Compromiso de los Agentes Económicos y Sociales 2018-2020. Available online: https://www.miteco.gob.es/es/calidad-yevaluacion-ambiental/temas/economia-circular/.pdf (accessed on 25 September 2021).

26. Gobierno de España, Ministerio de Agricultura y Pesca, Alimentación y Medioambiente. Ministerio de Economía, Industria y Competitividad. España Circular 2030. Estrategia Española de la Economía Circular. 2018. Available online: https://www. miteco.gob.es/images/es/180206economiacircular_tcm30-440922.pdf (accessed on 25 September 2021).

27. Instituto Nacional de Estadística. Censo de Población y Viviendas 2011. INE, 2011. Available online: https://www.ine.es/ censos2011_datos/cen11_datos_resultados.htm (accessed on 25 September 2021).

28. Gobierno de España, Ministerio de Fomento; Universidad Politécnica de Madrid. Análisis de las Características de la Edificación Residencial en ESPAÑA en 2011. 2011. Available online: https:/ / m.fomento.gob.es/NR/rdonlyres/BDE3A416-114C-498B-9F1A0286545535E0/135889/TomoII_Fichasestatalyautonomicas.pdf (accessed on 25 September 2021).

29. Domínguez-Amarillo, S.; Sendra, J.J.; Oteiza, I. La Envolvente Térmica de la Vivienda Social. El caso de Sevilla, 1939 a 1979. CSIC, 2019. Available online: http:/ / editorial.csic.es/publicaciones/libros/12659/0/la-envolvente-termica-de-la-vivienda-social-elcas.html (accessed on 25 September 2021). 
30. Cal, F.D.; Garrido-Marijuan, A.; Eguiarte, O.; Arregi, B.; Romero-Amorrortu, A.; Mezzasalma, G.; Ferrarini, G.; Bernardi, A. Energy Performance Assessment of Innovative Building Solutions Coming from Construction and Demolition Waste Materials. Materials 2021, 14, 1226. [CrossRef]

31. Tejero-González, A.; Krawczyk, D.A.; Martín-Sanz García, J.R.; Rey-Martínez, F.J.; Velasco-Gómez, E. Improved Performance of a PV Integrated Ventilated Façade at an Existing nZEB. Energies 2019, 12, 3033. [CrossRef]

32. Mercader-Moyano, P.; Esquivas, P.M.; Muntean, R. Eco-Efficient Analysis of a Refurbishment Proposal for a Social Housing. Sustainability 2020, 12, 6725. [CrossRef]

33. Guajardo, A. Análisis tipológico de bloques lineales de vivienda social: España 1950-1983. El caso de Andalucía occidental. Informes de la Construcción 2017, 69, 545. Available online: http://informesdelaconstruccion.revistas.csic.es/index.php/ informesdelaconstruccion/article/view/5832/6780 (accessed on 25 September 2021). [CrossRef]

34. CYPE; Ingenieros, S.A. Software for Architecture, Engineering and Construction. Open BIM Quantities. Measurement and Budgets of BIM Models. 2021. Available online: http:/ /2022.novedades.cype.es/2022_open_bim_quantities.htm (accessed on 25 September 2021).

35. CYPE; Ingenieros, S.A. Software for Architecture, Engineering and Construction. CYPE Architecture. Design and 3D Modeling of Buildings. 2021. Available online: http:/ / www.cype.es/ (accessed on 25 September 2021).

36. CYPE; Ingenieros, S.A. Software for Architecture, Engineering and Construction. CYPE Architecture. Construction Price Generator. 2021. Available online: http:/ / www.generadordeprecios.info/\#gsc.tab=0 (accessed on 25 September 2021).

37. Results Viewer of the Unified Tool for Verification of DB-HE 2019. 2020. Available online: https: / / oscarredondorivera.weebly. com/visualizador-resultados-hulc.html (accessed on 25 September 2021).

38. Código Técnico de la Edificación. Documento Básico de Salubridad, HE. CTE-DB-HE, 2019.

39. Rincón Abril, N.G.; Medina Becerra, I.D. Analysis of Sustainable Construction Versus Conventional Construction from the Point of View of Costs and Benefits: Toibita Refuge Case, Paipa-Boyacá. Available online: https:/ / revistas.unilibre.edu.co/index.php/ inge_libre/article/view/5942/5480 (accessed on 25 September 2021).

40. Marrero, M.; Martínez-Escobar, L.; Mercader, M.P.; Leiva, C. Minimization of the environmental impact in the execution of facades through the use of recycled materials. Constr. Rep. 2013, 65, 89-97. [CrossRef]

41. Base de Costes de la Construcción en Andalucía. Junta de Andalucía. BCCA, 2017. Available online: https://www. juntadeandalucia.es/index.html (accessed on 25 September 2021).

42. Instituto Eduardo Torroja de Ciencias de la Construcción con la Colaboración de CEPCO y AICIA. Catálogo de Elementos Constructivos del Código Técnico de la Edificación. 2018. Available online: https:/ / www.codigotecnico.org/index.html (accessed on 25 September 2021).

43. Banco Estructurado de Elementos Constructivos (BEDEC). Instituto Técnico de la Construcción de Cataluña (iTeC). 2020. Available online: https:/ /itec.es/servicios/bedec/ (accessed on 25 September 2021).

44. Mercader-Moyano, P. Cuantificación de los Recursos Consumidos y Emisiones de CO2 Producidas en las Construcciones de Andalucía y sus Implicaciones en el Protocolo de Kioto. Universidad de Sevilla. 2010. Available online: https://idus.us.es/ handle/11441/15660 (accessed on 25 September 2021).

45. Environmental Declaration of Products. AENOR Website. Available online: https://www.aenor.com/certificacion/certificacionde-producto/declaraciones-ambientales-de-producto (accessed on 25 September 2021). 